\title{
La oficialidad del ejército y la marina borbónicos: reformismo, fidelidad e identidad (1750-1808) $)^{1}$
}

\author{
Antonio Calvo Maturana ${ }^{2}$
}

Recibido: 15 de julio de 2016 / Aceptado: 13 de septiembre de 2016

Resumen. El presente trabajo es un estudio cultural de la oficialidad del ejército y la marina borbónicos en la segunda mitad del siglo XVIII. A través de casos y autores significativos, se analizará la imagen que la propaganda oficial quiso ofrecer de la élite militar, así como la recepción de esta por parte de dicha élite. Tanto en las relaciones verticales del oficial (Dios y el rey), como en las horizontales (patria, ciudadanía y amistad) se pueden identificar muchos de los debates propios del siglo, que pusieron a prueba los referentes de los servidores de la monarquía y trastocaron sus esquemas de obediencia y fidelidad.

Palabras clave: oficiales; ejército borbónico; patria; nación; Morla; Cadalso; Jorge Juan; Ilustración; reformismo; siglo XVIII.

\section{[en] Officers of the Bourbon Army and Navy: Reform, Loyalty and Identity (1750-1808)}

Abstract. This essay looks at Spanish Officers of the Bourbon Army and Navy during the second half of the XVIII Century from a cultural perspective. Relevant case studies will enable an analysis of the image provided by royal propaganda as well as an overview of its reception amongst this elite. Officers' vertical relationships (God and the king) as well as their horizontal relationships (homeland, citizenship and friendship) can be related to many areas of debate in that century, debates which tested and disrupted the cosmogony of these servants of the Absolute Monarchy.

Keywords: Officers; Bourbon Army; Homeland; Nation; Morla; Cadalso; Jorge Juan; Enlightenment; Reformism; XVIII Century.

Sumario. 1. El arquetipo de oficial ilustrado. 2. El arte de la guerra. 3. Poder civil, poder militar. 4. Soldado católico, soldado patriota. 5. La oficialidad en el contramodelo (reflexiones finales).

Cómo citar: Calvo Maturana, A. (2016) La oficialidad del ejército y la marina borbónicos: reformismo, fidelidad e identidad (1750-1808), en Cuadernos de Historia Moderna 41.2, 467-495.

\footnotetext{
1 Miembro de los proyectos del Ministerio de Economía y Competitividad del Gobierno de España: Liberalismo y antiliberalismo en España e Hispanoamérica, 1780-1840: discursos, actores y prácticas (HAR2013-42563-P) y La cultura literaria de los exilios españoles en la primera mitad del siglo XIX, CLEX 19 (FFI2013-40584-P).

2 Universidad Complutense de Madrid (España) ajcalvo@ghis.ucm.es
} 
En 1804, Tomás de Morla, capitán general del reino de Granada, fue denunciado a la Inquisición por la publicación de un polémico bando con fecha de 1 de octubre. El texto no era sino un intento de convencer a la población de que tenía que cambiar sus costumbres si quería detener el avance de la fiebre amarilla que estaba asolando Andalucía y que amenazaba con extenderse al resto del país.

Dos fueron las afirmaciones del pragmático Morla que motivaron la delación al Santo Oficio. La primera, en relación a las reuniones del pueblo en procesiones e iglesias que, lejos de ayudar a extinguir la epidemia, tentaban a Dios "exigiendo el milagro de que un contagiado no infecte a los inmediatos". La segunda afirmación impía, relacionada con la anterior, era su insinuación de que el culto exterior era inútil, siendo la religiosidad un proceso interior. En opinión del delator, el bando "fomenta y enorgulla la irreligión de la multitud de fanáticos libertinos que nos rodea"; la Inquisición ordenaría la retirada del texto. ${ }^{3}$

Episodios como este reflejan a la perfección el arquetipo de la oficialidad ilustrada. Morla, un racionalista formado en la Academia de Artillería de Segovia, se opone frontalmente a la superstición popular para defender el bien común. Al frente del ejército aplica las directrices del gobierno sobre salud y orden público, pero acaba chocando con la inmovilista Inquisición.

En palabras de la profesora Herrero Fernández-Quesada, Tomás de Morla puede ser considerado un "retrato robot" del oficial borbónico; en su formación científica, su anticlericalismo (que demuestra en su correspondencia con Godoy ${ }^{4}$ ) y su desprecio al populacho (exhibido tras la rendición de Madrid $^{5}$ ), identificamos al servidor tipo de la monarquía ilustrada, consecuencia de décadas de reformismo.

En las próximas páginas, en el contexto de un monográfico sobre la milicia borbónica española, haremos un estudio político y cultural de la oficialidad del ejército y la marina ilustrada en la línea del ya hecho sobre la élite política e intelectual ${ }^{6}$, de la que también formaron parte los militares. Es en las élites, en este caso en los oficiales, donde hemos de buscar los principales rastros del siglo ilustrado, de su debate entre modernidad y tradición y entre civilismo y militarismo, así como de su juego de fidelidades políticas con el asentamiento del trinomio Dios, patria y rey.

Por lógicos motivos de disponibilidad de espacio, no se aspira aquí sino a plantear una serie de temas (o calas, que diría Domergue) que nos acerquen al mencionado colectivo. Situando como referencia al arquetipo de oficial dieciochesco proyectado por la propaganda oficial (científico, noble, patriota, pío...), una serie de imágenes (nítidas unas, distorsionadas otras), de esta élite nos ayudaran a comprender qué esperaba la monarquía de la oficialidad y cómo se percibía esta a sí misma; hasta qué punto cabe hablar del ejército como colectivo aparte y no como un simbólico trasunto de la dialéctica dieciochesca Corona/élites/reformismo; o qué aspectos de la identidad y el juego de fidelidades de la oficialidad anticipaba la

3 Archivo Histórico Nacional (AHN), Inquisición, leg. 4.459; Herrero FernáNDEZ-QuESADA, Mª D.: Ciencia y milicia en el siglo XVIII: Tomás de Morla, artillero ilustrado, Madrid, UCM, 1990, vol. II, pp. 931-949 (o la edición de Segovia, Patronato del Alcázar, 1992).

$4 \quad$ Ibidem, p. 866.

5 La noticia de la capitulación de Madrid, publicada en la Gazeta del gobierno de 6 de enero de 1809, censuraba a Morla por haberse referido al pueblo como "populacho".

6 Calvo Maturana, A.: “Cuando manden los que obedecen”: la élite politica e intelectual de la España preliberal (1780-1808), Madrid, Marcial Pons, 2013. 
contemporaneidad. Espero que mis colegas, sobre todo los especialistas en historia militar, aprueben y disculpen esta "golillesca" pero bienintencionada intrusión.

\section{El arquetipo de oficial ilustrado}

Las reformas borbónicas del ejército llevaron aparejadas un modelo de oficial que simbolizaba la efectividad, el reformismo y el compromiso que se esperaba de la nueva milicia. El oficial dieciochesco (figura que despertó las fantasías románticas de un joven Rousseau ${ }^{7}$ ), noble, educado en las academias y dotado de un sueldo más o menos digno que permite su profesionalización, es ensalzado por la propaganda gubernamental, que se centra claramente en la élite militar para dejar de lado al soldado raso ${ }^{8}$ En esta línea, el coronel Bernardo María de la Calzada tradujo una obra que presenta una dual imagen del ejército dieciochesco; mientras que el oficial es el ejemplar espejo de sus soldados, estos son, en su mayoría "la más vil canalla del pueblo, como vagamundos, y libertinos" y el ejército "una asociación de pícaros".

La clave para la formación de esta élite de oficiales es la figura del cadete, o alumno de academia militar ${ }^{10}$, al que las ordenanzas exigían ser hidalgo y tener los medios suficientes para pagarse su manutención. ${ }^{11}$ Del joven cadete se esperaba que supiese leer y escribir, que fuese capaz de estudiar, que tuviese "buena traza" y buen comportamiento. ${ }^{12}$ La semblanza que Bails hizo de Jorge Juan viene a coincidir con estas premisas. Además de estudioso,

fue de estatura y corpulencia medianas, de semblante agradable y apacible, aseado sin afectación en su persona y su casa, parco en el comer, el igual de sus subalternos, el amigo de sus criados, y por decirlo todo en menos palabras, sus costumbres fueron las de un filósofo cristiano. ${ }^{13}$

En 1805, Godoy quiso reforzar el perfil de la oficialidad como élite cultural al crear el Instituto Militar Pestalozziano, al que tenían acceso preferentemente los hi-

“Acompañábanme mis gratas quimeras, y nunca las imaginó más bellas mi ardiente fantasía (...) Aquella vez eran marciales mis ideas. Iba a juntarme con un militar y a serlo yo también, pues hubo de acordarse que yo entraría de cadete. Ya me veía vestido con el uniforme de oficial, con un magnífico plumero blanco. Este noble pensamiento dilataba mi corazón (...) Tanto me entusiasmaba con tales desvaríos, que por doquiera solo veía tropas, murallas, gaviones, baterías, y me consideraba en medio del humo y del fuego dictando órdenes tranquilamente, con el anteojo en la mano". Rousseau, J. J.: Las confesiones, Madrid, Espasa, 1983, p. 149.

8 Las fuentes constatan las dificultades de la Corona para completar los regimientos con voluntarios y la necesidad de recurrir a las quintas, boicoteadas por las autoridades municipales y las deserciones. Para el reinado de Felipe V, véase: OYA, F. de la: Tratado de las levas, quintas y reclutas de gente de guerra, Madrid, Antonio Marín, 1734.

9 Brucourt, C. F. O. Rosette, Chevalier de: Ensayo sobre la educación de la Nobleza. Lo escribió el Caballero... y trasladó al castellano Don Bernardo María de Calzada, Madrid, Imprenta Real, 1792, tomo II, p. 367.

10 Centros de formación como la Academia de Guardias Marinas de Cádiz o la de Artillería de Segovia intentaron paliar la falta de preparación de los oficiales, pero nada se hizo para formar al soldado raso. La necesidad de la fundación de centros con este propósito ya había sido expuesta en el siglo anterior por Siego de Saavedra Fajardo en la LXXXII de sus Empresas politicas.

11 Ordenanzas de S.M. para el régimen, disciplina, subordinación y servicio de sus dos ejércitos, subdividido en tres tratados de Orden de SM, Madrid, Oficina de Antonio Marín, 1768, art. I, p. 236.

12 Instrucción de lo que deben practicar los pretendientes a plaza en el Real Colegio Militar de Caballeros Cadetes del Real Cuerpo de Artillería para lograr su admisión en él, Madrid, Ibarra, 1777, pp. 9-10.

13 BAILs, B.: Elogio de Don Jorge Juan, ca. 1779, p. 19. 
jos de oficiales y los jóvenes cadetes. La orientación castrense de sus estudios es más que manifiesta en el plan de estudios (en el que tenía peso la gimnástica militar) y en su reglamento:

Siendo uno de los objetos de este Instituto el de formar con el tiempo buenos defensores del Estado, se procurarán organizar militarmente todas las operaciones interiores, usando tambor en lugar de campana, e inspirando a los niños las virtudes militares y civiles que pueden aprender desde los más tiernos años. ${ }^{14}$

La política de prestigio en torno a la élite militar aparece plasmada en las fuentes de la época, tanto las tratadísticas como las literarias. Antonio Pérez y López escribió en 1781 que el de oficial del ejército era "el empleo más honorífico del reino". ${ }^{15}$ En El sí de las niñas, Don Diego recordaba a su sobrino Don Carlos el liderazgo espiritual que conllevaba su puesto: "Un oficial siempre hace falta a sus soldados. El rey le tiene allí para que los instruya, los proteja y les dé ejemplo de subordinación, de valor, de virtud". ${ }^{16}$ La misma prensa oficial recogía los ascensos, los premios y las victorias de los militares.

Aunque ese modelo de militar se puede rastrear incipientemente en los círculos ilustrados de la primera mitad del XVIII ${ }^{17}$, es en la segunda cuando aparece con mayor intensidad, tras hitos que representan la consolidación del nuevo modelo de ejército, como la fundación de la Academia de Artillería de Segovia o el despunte de personajes como los guardias marinas de formación Jorge Juan y Antonio de Ulloa. El científico, expedicionario y pedagogo Jorge Juan, director de la Academia de Guardias Marinas de Cádiz y del Seminario de Nobles de Madrid, diplomático y espía, es un ejemplo casi arquetípico de este modelo de oficial formado en las Academias. $^{18}$

Fue Jorge Juan, con apoyo de la Imprenta Real, portavoz (aunque fuese póstumamente) del carpetazo oficial al geocentrismo. En su Estado de la astronomía aposta-

$14 \quad$ Noticia de las providencias tomadas por el gobierno para observar el nuevo método de la enseñanza primaria de Enrique Pestalozzi... De orden superior, Madrid, Imprenta Real, 1807, p. 67.

15 PÉRez y LóPez, A. X.: Discurso sobre la honra y deshonra legal, Madrid, Blas Román, 1781, p. 145.

16 Fernández de Moratín, L.: El sí de las niñas, Madrid, Cátedra, 2003, p. 152. Aún más se debía esperar de los escalafones más altos del ejército. Para Antonio Eximeno, en su oración por la apertura de la Academia de Artillería de Segovia, el "oficial general” debía ser a la vez "un gran matemático, un grande histórico, un gran político, un gran filósofo, un héroe”, además de una persona equilibrada capaz de mirar a la vez por el bien de la tropa y el de la nación. Eximeno, A.: Oración que en la abertura de la Real Academia de caballeros cadetes del Real Cuerpo de Artillería nuevamente establecida por S.M. en el Real Alcázar de Segovia, dijo..., Madrid, Eliseo Sánchez, 1764, pp. 16-17.

17 Así, las influyentes Reflexiones militares (1724-1730) del marqués de Santa Cruz de Marcenado presentan un modelo de oficialidad de sesgo humanista, interesado en el estudio y con virtudes aplicables al gobierno del ejército; "un paradigma humano muy distinto al del hombre barroco, porque, en lugar de educar para el desengaño en la existencia terrena y conocer la futilidad de las cosas temporales, el Marqués se fija en las premisas de un buen gestor de la ciudad terrena". Sánchez-Blanco, F.: La Ilustración Goyesca. La cultura en España durante el reinado de Carlos IV, 1788-1808, Madrid, CEPyC, CSIC, 2007, pp. 114-116. No obstante, encontramos en las primeras décadas del siglo restos del modelo militar barroco. Por ejemplo, Santa Cruz de Marcenado aún valoraba la experiencia sobre el aprendizaje, y consideraba inapropiado que el general emplease su tiempo en leer algo que no estuviera relacionado con el arte de la guerra. GARCíA HuRTADo, M. R.: El arma de la palabra. Los militares y la cultura escrita en el siglo XVIII (1700-1808), A Coruña, Universidade da Coruña, 2002, p. 57.

18 Alberola Romá, A., Mas Galván, C. y Die Maculet, R. (eds.): Jorge Juan Santacilia en la España de la Ilustración, Alicante, Universidad de Alicante, 2015; Jorge Juan y la Ciencia Ilustrada en España. XLVII Jornadas de Historia Maritima. Ciclo de Conferencias, noviembre 2013, Madrid, Ministerio de Defensa, 2013; VAlVERde, N.: Un mundo en equilibrio. Jorge Juan (1713-1773), Madrid, Marcial Pons, 2012. 
ba por una adopción sin paliativos de las tesis heliocentristas sin que eso implicase la más mínima agresión a la fe: "no hay reino [europeo] que no sea Newtoniano, y por consiguiente Copernicano, mas no por eso pretenden ofender (...) a las Sagradas letras, que tanto debemos venerar". El verdadero ultraje a la Santas Escrituras era, por el contrario, pretender que estas se opusieran a la verdad científica. Era, en definitiva, labor del rey sacar a sus vasallos del error y del ridículo internacional, evitando que siguiese haciéndose "risible una Nación que tanta ceguedad mantiene". ${ }^{19}$

Sobre el cultivo de las letras por parte de los militares ya existe una solvente monografía. ${ }^{20}$ Sabemos que el gremio no fue en absoluto ajeno a la escritura, y que por el contrario fue prolijo en textos vinculados a la profesión, como tratados y manuales sobre fortificaciones, matemáticas, ingeniería, balística o cirugía, obras en las que la pragmática ilustración española, centrada en las ciencias aplicadas, es capaz de dialogar con la europea. En ese sentido, la "militarización de la ciencia española de la Ilustración" es innegable. ${ }^{21}$ Encontramos en estos autores una considerable capacidad de trabajo, demostrada también por su colaboración con textos no publicados como informes, censuras y arbitrios. Se trata al fin de "intelectuales orgánicos" 22 , que participaron activamente en la república de las letras,

no escriben tanto por necesidad de crear (prosa, poesía, teatro) como por la aparición en la carrera militar de una faceta que hasta el XVIII es desconocida. Esta nueva dedicación militar se halla en consonancia con el surgimiento de academias militares, las escuelas regimentales, la proliferación de tratados militares en el extranjero y las reformas orgánicas y tácticas de la época, que obligan a dejar negro sobre blanco los adelantes que está viviendo la ciencia de la guerra en todos sus aspectos: armas, barcos, disposición de tropas, etc. ${ }^{23}$

La temática de los autores militares sobrepasa la del propio ejército. Poco queda por decir ya del ensayista y poeta Cadalso. También hubo militares vinculados a la prensa $^{24}$, como fue el caso de Aguirre y el Correo de los ciegos. De Bernardo María de la Calzada hemos de destacar su labor como traductor de Voltaire, Condillac y Racine. ${ }^{25}$ De Vicente de los Ríos, su famosa edición del Quijote. Estos tres autores pueden ser situados en la vanguardia del pensamiento ilustrado español.

Aunque en menor medida que los militares, autores civiles y religiosos también se preocuparon por el tema del ejército, sobre todo de materias consideradas anejas a él como la ciencia y la religión. Alguno de estos escritores u oradores se excusaba

19 Juan, J.: Estado de la astronomía en Europa, Madrid, Imprenta Real de la Gazeta, 1774, pp. 14-15. La Revolución Científica se instauró en la tratadística militar española del XVIII. Cipriano Vimercanti, totalmente adepto al heliocentrismo, reconocía que Copérnico había causado "en los entendimientos" una "singular" y "prodigiosa mudanza", y manifestaba su admiración por otros científicos como Kepler, Newton, Descartes y Leibniz. Vimercati, C.: Prolusión académica sobre el origen y progresos de la astronomía hasta nuestra edad..., Madrid, Imprenta de Don José de Urrutia, 1790, p. 54.

20 García Hurtado, op. cit. (nota 17).

21 Lafuente, A. y Valverde, N.: Los mundos de la ciencia en la Ilustración española, Madrid, FECT, 2003.

22 Álvarez Barrientos, J.: Los hombres de letras en la España del siglo XVIII. Apóstoles y arribistas, Madrid, Castalia, 2006.

23 García Hurtado, op. cit. (nota 17), p. 265.

24 Ibidem, pp. 218-219.

25 Freire López, A.: "Un traductor del reinado de Carlos III; Bernardo de Calzada", en De la Ilustración al Romanticismo. IV encuentro: Carlos III: dos siglos después, Cádiz, 7-9 de abril de 1988, Cádiz, Universidad de Cádiz, 1993. 
humildemente ante un público militar diciendo sentirse como Formión, el filósofo que fastidió al cartaginés Aníbal dándole lecciones sobre el arte de la guerra. ${ }^{26}$ Entre los autores no militares que escribieron para la milicia podemos citar a los jesuitas vinculados a la enseñanza en las Academias antes de la expulsión. "Moriré gustoso [exclamó el religioso Antonio Eximeno] empuñando la pluma para enseñar a mis discípulos a morir con la espada en la mano". ${ }^{27}$

Hablamos de escritores militares, pero también de lectores, como prueban sus bibliotecas o sus suscripciones a la prensa y sus permisos para consultar libros prohibidos. Las lecturas de algunos militares como Churruca y Ricardos y las sospechas sobre sus ideas despertaron la desconfianza del Santo Oficio. ${ }^{28}$

Los militares participaron en las instituciones culturales y de sociabilidad de la monarquía. Los vemos, como miembros de Academias (los marinos Vargas Ponce y Fernández de Navarrete fueron académicos de la Historia) y Sociedades, concurrir a premios y dar discursos. Conocemos la participación de varios de ellos en iniciativas gubernamentales ilustradas, como a Francisco Amorós, implicado en proyectos educativos como el Instituto Pestalozziano. ${ }^{29}$

Esbozado el arquetipo cultural, es momento ahora de hacer una pequeña semblanza social. Las reformas borbónicas blindaron el acceso a la oficialidad a través del mérito militar al estipular que el oficial dieciochesco había de ser noble. La mencionada figura del cadete, que requería la pertenencia a la clase nobiliaria, dotó al ejército de un prestigio y una honorabilidad que lo hicieron sugerente para una clase que en el siglo anterior se había distanciado de la carrera de las armas. ${ }^{30}$ Por otra parte, como ha demostrado el profesor Andújar, el ejército se convirtió en un vehículo de ennoblecimiento que el rey ofertó a cambio de servicios venales ${ }^{31}$, considerados como positivos por el mismo Montesquieu. Así, la milicia sirvió a la vez para reclutar a la nobleza al servicio del Estado, para incentivar a los sectores adinerados del pueblo llano a invertir en la causa regia, y para dinamizar y aliviar parte de las tensiones de la rigidez propia de la sociedad estamental.

Los tratados dieciochescos presentaban una vinculación atávica entre nobleza y milicia, remontándose por lo general a tiempos remotos en los que los más ilustres y poderosos se habían erigido en defensores del pueblo. García de la Huerta escribió que "es la milicia herencia de los nobles, pues desde que se conoce el arte de ella, ha estado vinculada a los más ilustres personajes" ${ }^{32}$; mientras que el conde de Aranda recordaba a Carlos III que los honores militares no debían ser extendidos más allá

26 Por ejemplo, Antonio Eximeno en la Oración de apertura de la Academia de Artillería de Segovia (p. 17) y Clemente Peñalosa en El honor militar (p. 6).

27 EXIMENO, op. cit. (nota 16), p. 22.

28 LARriBA, E.: El público de la prensa en España a finales del siglo XVIII, Zaragoza, Universidad de Zaragoza, 2013, pp. 316.

29 Vid. Fernández Sirvent, R.: Francisco Amorós y los principios de la educación fisica moderna, Alicante, Universidad de Alicante, 2005.

30 Andútar CAStillo, F.: Los militares en la España del siglo XVIII. Un estudio social, Granada, Universidad de Granada, 1991. Aunque también despertó las críticas de ilustrados como Cabarrús, que consideraban que un ejército nobiliario era una cantera de "violetos" y que perjudicaba al Estado que se valorase "el mérito de los abuelos en vez de fijarse exclusivamente en el personal del individuo que le ha de servir". CABARrús, F.: Cartas sobre los obstáculos que la naturaleza, la opinión y las leyes oponen a la felicidad pública, cit. por ANDÚJAR, op. cit. (nota 30), pp. 417-418.

31 Andújar, F.: El sonido del dinero. Monarquía, ejército y venalidad en la España del siglo XVIII, Madrid, Marcial Pons, 2004.

32 García de la Huerta, V.: Bibliotheca Militar Española, Madrid, Antonio Pérez de Soto, 1760, p. 1. 
de la milicia pues "han sido los ejércitos el destino de las gentes distinguidas. La nobleza de todas las naciones viene de aquellos antiguos héroes que se sacrificaban por su patria y reyes". ${ }^{33}$ Clemente Peñalosa acudía incluso a argumentos de índole naturalista: "Los nobles por tradición natural, que las primeras leyes del Estado consagran, nacieron para mandar los ejércitos". ${ }^{34}$ Argumentos similares, fundamentados en un estado casi de naturaleza en el que la sociedad comenzó a organizarse, utilizarían Joaquín Marín Mendoza en su Historia de la Milicia española (1776), Mariano Madramany en su Discurso sobre la nobleza de las armas y las letras (1790) o José María Lezpona en su Discurso en elogio de la milicia (1808).

Resulta por tanto perfectamente lógico que Peñalosa dedicase varias páginas de su obra sobre El honor militar a la nobleza. "España debió su grandeza, su libertad y la gloria de su nombre a nobles, cuya sangre derramada" sembró la resistencia contra la invasión sarracena medieval. ${ }^{35}$ Por mucho que fuese propio del siglo criticar al estamento nobiliario, no le cabía duda al autor de que cualquiera de sus críticos estaría encantado de acceder a él: "Continuamente se grita contra la Nobleza, pero no hay uno que no quisiera ser noble. Esta manía me parece semejante a la extravagancia de Séneca, que después de poseer inmensas riquezas, hizo el elogio de los pobres". ${ }^{36}$

Por otra parte, continúa Peñalosa, la nobleza exige al militar que honre a sus antepasados y a su condición, demostrando el valor que se le presupone. Si los militares nobles no son fieles a la sangre heroica que corre por sus venas, "ofenden las intenciones que la sociedad se propuso en su elevación, degradan su dignidad y menosprecian lo mismo a que debieron sus honras, que es la virtud". ${ }^{37}$

Sin duda, el culto dieciochesco a la utilidad pública está muy presente en el ejército. ${ }^{38} \mathrm{El}$ contramodelo del oficial ilustrado, retratado por Cadalso, es el "militar a la violeta", aquel que adopta exclusivamente la vertiente frívola y pendenciera de la profesión, y solo piensa en acicalarse y pavonearse en los cafés sin preocuparse por tener una formación en el arte militar más allá de la aparente. El mal militar confunde el refinamiento y la urbanidad dieciochescas con el amaneramiento, y la crítica a los malos usos pasados con un desprecio total a la honrosa tradición militar castellana. ${ }^{39}$ Por su parte, el panegirista de José Urrutia pedía al resto de la milicia que imitase a su difunto capitán general, siempre volcado en el "beneficio común de la nación" y en "vivir para sus conciudadanos", incluso en los días de paz, empleándolos en instruir-

33 Aranda, conde de: Memorial del conde de Aranda a Su Majestad sobre las quejas del ejército por los Reales Decretos en que se extendian los mayores honores militares a los campos pacificos del Estado. Madrid, 27 de mayo de 1788, Biblioteca Nacional (BN), Manuscritos (Ms.) 7.166, ff. 10-11.

34 Peñalosa y ZúÑIga, C.: El honor militar: causas de su origen, progresos y decadencia, o correspondencia de dos hermanos desde el ejército de Navarra de S.M.C., con orden real, Madrid, Benito Cano, 1795, pp. 35-36.

35 Ibidem, p. 46.

36 Ibidem. p. 42.

37 Ibidem. p. 35.

38 Por ejemplo, el discurso IV del Censor incluye el servicio en la milicia entre las labores que Eusebio podía hacer al servicio del bien público, del mismo modo que el CLXII lo menciona en su alegato por una nobleza útil al Estado. En el discurso LXI, el famoso Viaje a la tierra de los Ayparchontes hace del ejército un instrumento de glorificación personal, incluso de redención social para los infames: "[Entre los Ayparchontes] Hay un cuerpo de tropas en que pueden alistarse y que es siempre empleado en las ocasiones más peligrosas. Y es tal el ardor que inspira, a los que le componen, el deseo de salir del abatimiento en que se hallan, que no se lee en los anales de aquel imperio acción gloriosa ni batalla señalada en que no hayan tenido la principal parte". Discurso LXI. 19 de febrero de 1784 ["Viaje a la tierra de los ayparchontes"], El Censor. Edición de Francisco Uzcanga, Barcelona, Crítica, 2005, pp. 157-164 y 158-159.

39 CADAlso, J.: El buen militar a la violeta, Sevilla, Imprenta de la ciudad, 1790. 
se y no "en la indolencia y en los placeres". ${ }^{40}$ En el elogio a Jorge Juan aprendemos que este no hizo de su noble cuna "un privilegio para vivir inútil, antes porque nació distinguido quiso distinguirse por varios caminos y merecer por sí lo que ya tenía de la casualidad". ${ }^{41}$ Llama la atención el uso de la palabra "casualidad", que nos recuerda en cierta manera a la famosa definición cadalsiana de nobleza. ${ }^{42}$

El oficial dieciochesco fusiona, por tanto los atributos profesionales que se esperan de un miembro del ejército y los sociales propios del noble ilustrado ${ }^{43}$, muchos de ellos confluyentes. De ahí que el conde de Aranda, a pesar de la evidente profesionalización de la milicia y de la importancia de la instauración del salario, siguiese defendiendo en sus escritos de finales de siglo una visión nobiliaria y honorífica de la milicia.

\section{El arte de la guerra}

En agosto de 1783 y julio de 1784, Antonio Barceló dirigió los dos bombardeos de Argel con los que Carlos III pensaba forzar a esa regencia a poner fin al corso contra los barcos españoles en el Mediterráneo. A pesar de los modestos resultados de ambas acciones, y en el contexto de un año de fuerte propaganda monárquica derivada del nacimiento de los infantes gemelos, numerosos autores se lanzaron al elogio de Barceló y del monarca mediante unas composiciones tan pobres literariamente como grandilocuentes que pronto despertaron el desprecio de los autores neoclásicos.

Los dos elogios más conocidos fueron los firmados por el autor de la famosa $R a$ quel, Vicente García de la Huerta ${ }^{44}$, un contradictorio autor al que su nostalgia de la España barroca (sin ser él un autor barroco) lo convirtió en el objeto de los ataques de los autores neoclásicos. Esta polémica en concreto nos interesa por dos estrofas particularmente polémicas de los Endecasílabos (...) con motivo del bombardeo de Argel en las que Huerta ensalza a Barceló ("un marino hecho en el mar y no en las aulas de una academia"45) por sus conocimientos prácticos, adquiridos sin necesidad de estudio:

\footnotetext{
Forma el ataque: distribuye, regla

con oportunidad la más exacta,

sin sujeción a inciertas teorías,

movimientos, lugares y distancias;
}

40 Hernández de Morejón, S.: Elogio del Excelentísimo Señor Don Josef de Urrutia y las Casas..., Palencia, Álvarez, Palencia, Álvarez, 1801, pp. 14-16.

41 BAILs, op. cit. (nota 13), p. 2.

42 "Nobleza hereditaria es la vanidad que yo fundo en que, ochocientos años antes de mi nacimiento, muriese uno que se llamó como yo me llamo, y fue hombre de provecho, aunque yo sea inútil para todo". CADALSO, J.: Cartas Marruecas, Madrid, Espasa, 1999, carta XIII, p. 88.

43 Andútar Castillo, F.: "Poder militar y poder civil en la España del siglo XVIII. Reflexiones para un debate", Melanges de la Casa de Velázquez, 28-2 (1992), pp. 55-70 y 66.

44 Unos Endecasílabos (...) con motivo del bombardeo de Argel, Barcelona, Fulalia Piferrer, 1783 y un Elogio del Excelentísimo Señor D. Antonio Barceló, Madrid, Hilario Santos Alonso, 1784.

45 Guastavino Gallent, G.: Los bombardeos de Argel en 1783 y 1784 y su repercusión literaria, Madrid, CSIC, 1950, p. 13. 
Que en un alma sublime las ideas que dan a otros las Artes son innatas; y un Genio criador con el dominio de quien las puede producir, las trata (vss. 201-208).

Una Carta a Don Vicente García de la Huerta, escrita por el joven marino Martín Fernández de Navarrete, dio respuesta a los Endecasílabos y al Elogio de Huerta. Las polémicas literarias ilustradas podían envolver posicionamientos ideológicos. Las críticas neoclasicistas de Navarrete se mezclan con su visión ilustrada del mundo. Acierta J. A. Ríos al afirmar que: "Fernández de Navarrete intuye que el elogio a Barceló no estaba dirigido solamente a este personaje, sino que a través de él se revela una serie de matices ideológicos opuestos a los que él mismo y los detractores de nuestro autor [García de la Huerta] defienden". ${ }^{46}$

Fernández de Navarrete representaba un modelo de marino muy distinto a Barceló. Si este era un hombre sin estudios, que había ganado sus ascensos y su fama persiguiendo piratas desde los 18 años, aquel era un marino formado en el Seminario de Vergara y la Academia de Guardias Marinas de El Ferrol, cuya vasta cultura le llevaría a dirigir la Academia de la Historia.

Resguardado en su pseudónimo, Navarrete no se conformó con ridiculizar la verosimilitud y la calidad de estos elogios en general ("papeles tan indecorosamente tratados, que ni los confiteros para hacer cucuruchos los han de querer" ${ }^{47}$ ) y del de García de la Huerta en particular ${ }^{48}$ sino que se lanzó abiertamente a ridiculizar los efectos del ataque ${ }^{49}$, a criticar la utilidad de este tipo de expediciones ${ }^{50}$ y a menoscabar la fama de Barceló al que acusaba de atribuirse los méritos de otros, de haber ganado siempre en franca superioridad y de emprender sus acciones movido por "el amor propio, la ignorancia y la ambición", 51

Para alguien formado en el nuevo modelo de oficialidad, como Martín Fernández de Navarrete, el elogio de la ignorancia de Barceló por parte de García de la Huerta no podía pasar desapercibido. El polemista decía sentirse "escandalizado" por semejantes afirmaciones y preguntaba: “¿No sabe Vm. que para formar una escuadra en orden, varían estos según convenga, evitar o retardar el combate, saberlo sostener, etc., no basta el juicio y práctica sin que tenga la mayor parte el sólido estudio de la táctica naval, que debe ser el complemento de los que constituyen un buen Gral.?”.

46 Ríos Carratalá, J. A.: Vicente García de la Huerta (1734-1787), Badajoz, Diputación de Badajoz, 1987, p. 199. También se ha ocupado de esta polémica, más recientemente: DuRán LóPEz, Fernando: "García de la Huerta contra Fernández de Navarrete y Vargas Ponce, o lo que vale un enemigo", en Cañas Murillo, Jesús, Lama, Miguel Ángel y Roso Díaz, José (eds.): Vicente García de la Huerta y su obra (1734-1787), Madrid, Visor Libros, 2015, pp. 539-563.

47 Carta a don Vicente García de la Huerta, manifestándole algunos reparos críticos del Elogio que ha compuesto al Excmo. Sr. D. Antonio Barceló con motivo de la última expedición contra Argel..., en GuASTAVINO GALLENT, op. cit. (nota 45), apéndice IV, pp. 103-121/120.

48 García de la Huerta se refiere al "último horizonte". Añade Fernández de Navarrete "que sin duda debe estar muy lejos". Ibidem, p. 116.

49 “... exagera Vm. tanto el miedo, el susto, el terror, de los argelinos cuando hasta las mujeres estaban en los terrados de las Casas de Argel mirando con serenidad mucha los ataques”. Ibidem, p. 115. Efectivamente, Huerta utiliza un lenguaje que no concuerda con el espíritu militar del siglo, que tendía a regodearse poco en la violencia. Tampoco se adapta al protocolo neoclásico llamar al enemigo "vil chusma", como hace Huerta en el Elogio.

50 Considera el autor que son más efectivas y disuasorias la instalación de patrullas marinas y la asignación de escoltas. Ibidem, pp. 109-110.

51 Ibidem, p. 112. 
Pretendiendo sacar del defecto virtud, Huerta había puesto a Barceló “el borrón más denigrativo aún para el general más acreditado". Según Navarrete, la triste realidad era que las escuadras de jabeques de Barceló "siempre han andado dispersas y a la buena ventura" y que la falta de pericia técnica demostrada por el teniente general en Argel había supuesto un despilfarro de arsenal:

¿Y le parece a Vm. igualmente que, si este se hubiera sujetado a las teóricas ciertas (a pesar de Vm.) que presta la Artillería para conocimiento del alcance y la Navegación y Geometría para situarse en él, se hubiera desperdiciado este año cerca de cinco mil bombas y el año pasado la mayor parte?. ${ }^{52}$

Las palabras de Huerta eran además una mala influencia para la juventud ya que, en opinión de Navarrete, la podían privar "del estímulo y la aplicación a los estudios viéndolos calificados de débiles y sus teóricas de inciertas", haciendo inútil la política gubernamental a favor de los formación de oficiales o los "desvelos de S.M. en la fundación de Academias y dotaciones de Estudios para que en sus teóricas se imponga la Noble Juventud antes de llegar a la práctica". ${ }^{53}$

Esta defensa de la ciencia militar en detrimento de la experiencia, si bien era más una desiderata que una realidad ${ }^{54}$, se venía realizando en las academias militares, donde los oficiales escuchaban discursos en los que se elogiaba a Descartes, Kepler, Galileo, Newton y Leibniz, y estudiaban manuales en los que se fomentaba el conocimiento científico, situando a estos centros muy por delante de las universidades. En 1764, en el discurso de apertura de la Academia de Artillería de Segovia, el jesuita Antonio Eximeno dedicó varios pasajes a ensalzar la importancia de la formación teórica frente a la mera práctica, puesto que "ningún hombre es capaz de hacer por sí las experiencias necesarias para establecer un solo principio", añadiendo que "cuando se ensalza la práctica para abatir la teórica, se habla de mala fe". ${ }^{55}$ Por su parte, el teniente Vicente de los Ríos defendía en otro discurso que:

... como la base y fundamento de la Milicia es la teórica del arte de la guerra, que abraza una multitud maravillosa de conocimientos exquisitos, de ciencias sublimes, de doctrinas distantísimas; como este arte tiene sus reglas y preceptos, que es forzoso aprender y estudiar metódicamente para gobernarse por ellos en la práctica; y como la fuerza de los ejércitos, la felicidad de las armas, la salud de los Estados depende del progreso de este arduo y difícil estudio; por eso ha querido también radicarlo y perpetuarlo el Rey con el establecimiento de escuelas militares en los cuerpos de su ejército. ${ }^{56}$

$52 \quad$ Ibidem, p. 113.

53 Ibidem, p. 114. Evidentemente, los libros de texto de las Academias adoptan el punto de vista contrario al de García de la Huerta. En un manual de matemáticas escrito para los Guardias Marinas, leemos que es posible dar la vuelta al mundo sin más conocimientos que los prácticos, pero todo piloto que dé la espalda a la ciencia está expuesto a "fatales errores" y niega la posibilidad de ofrecer un mejor servicio al rey. Godín, L.: Compendio de matemáticas para el uso de los caballeros guardias marinas, Cádiz, Imprenta de la misma Academia, 1758.

54 “... el valor concedido a los estudios era muy escaso - por no decir que casi nulo- en una institución que consideraba que la mejor formación que podía recibir un futuro oficial era la experiencia directa en los campos de Marte". ANDÚJAR CASTILLO, F.: "El Seminario de Nobles de Madrid en el siglo XVIII. Un estudio social", Cuadernos de Historia Moderna. Anejo III (2004), pp. 201-225 y p. 206. Tanto la antigüedad como las relaciones personales pesaban considerablemente más que la preparación.

55 Añadiendo que: "La práctica es una esclava, cuya reina es la teórica, bien que esta reina depende absolutamente de la esclava". Eximeno, op. cit. (nota 16), pp. 14-15.

56 Ríos, V. de los: Discurso para la abertura de la escuela de táctica de artillería dicho en el Real Colegio militar de Segovia, Madrid, Joaquín Ibarra, Impresor de Cámara de SM, 1773, p. 6. 
Los manuales de estudio de las academias están vivos y son permeables a las novedades científicas. La reedición de 1790 del Compendio de navegación de Jorge Juan (1757) incluye actualizaciones, pues en tiempos del marino "todavía no estaba resuelto el problema de las observaciones de longitud en el mar". ${ }^{57}$

El apoyo del poder a este tipo de obras es notorio. Las academias militares ocupaban un papel importante en la propaganda monárquico-ilustrada. Tras la fundación del colegio de Artillería, el jesuita Tomás Cerda afirmó que "con esta nueva Academia de Segovia para la artillería, con la de Cádiz para la Marina, y con la de Barcelona para el resto del ejército, tiene S.M. para la educación de su tropa tres establecimientos que no los tiene mejores para su ejército ningún monarca de la Europa". ${ }^{58}$ La monarquía apoyó los textos científicos de diferentes maneras. Por ejemplo, publicándolos en la Imprenta Real (que dio a la luz póstumamente varios trabajos de Jorge Juan) o la Imprenta Real de la Marina, o mediante la cantidad de obras de temática militar publicadas "de orden del rey" o "de orden superior". También hemos de fijarnos en las dedicatorias, mal entendidas tradicionalmente como un gesto de adulación sin tener en cuenta las muchas que se rechazaban y el apoyo implícito al contenido de la obra por parte del "homenajeado" que suponen. ${ }^{59}$

No es de extrañar pues que, fuera de las academias y del ámbito militar, la importancia de las ciencias militares fuese generalmente aceptada. En 1790, Mariano Madramany destacaba que "las ciencias y las artes de la paz son necesarias en la misma guerra para emprenderla con prudencia y para concluirla con felicidad. Para que una pieza de artillería acierte el tiro, es menester que antes el ingenio la nivele y dirija al blanco su puntería". ${ }^{60}$ Incluso fray Diego de Cádiz, que no era precisamente un dechado de modernidad, advertía al soldado católico que estaba obligado en conciencia a formarse "en la ciencia y en el espíritu militar, que como esenciales a su estado le son en todo tiempo inseparables. ${ }^{61}$ En definitiva, una lectura de las fuentes del último tercio del XVIII demuestra lo antediluviano de los versos de Huerta.

Sin duda, el arquetipo de militar dieciochesco es una persona con formación en las ciencias útiles, que eran las que -en contraposición a las especulativas- interesaban al Estado. El teniente Enrique Ramos hablaba de las ventajas de "preferir a las verdades abstractas y de pura curiosidad, los conocimientos prácticamente útiles". ${ }^{2}$ El elogio fúnebre a José Urrutia cuenta cómo este "negose al estudio de

57 JuAn, J.: Compendio de navegación para el uso de los caballeros Guardias-Marinas, Isla de León, Imprenta de su Academia, 1790.

58 CERDA, T.: Lección de artillería para el uso de la clase, Barcelona, Francisco Suría, 1764.

59 Pedro Padilla y Arcos dedicó a Fernando VI su Curso militar de mathemáticas (1753-1756); Santiago Agustín de Zuloaga y Tomás de Morla dedicaron respectivamente a Carlos III un Tratado instructivo y práctico de maniobras navales para el uso de los Guardias-Marinas (1766) y un Tratado de Artillería (1782); Gabriel Ciscar pudo dedicar a Carlos IV su ampliación del Examen marítimo teórico práctico de Jorge Juan, al igual que Vicente Maturana hizo con su Ejercicio doctrinal y evoluciones de una brigada de artillería de a caballo (1800). Nobles y ministros también fueron objeto común de dedicatorias. Como muestra digamos que el Discurso sobre economía política de Enrique Ramos está dirigido al conde de Aranda (1769) y la Memoria sobre la artillería volante o de a caballo de Clemente Peñalosa a Godoy.

60 Madramany y Calatayud, M.: Discurso sobre la nobleza de las armas y las letras, Madrid, Benito Cano, 1790, p. 44.

${ }^{61}$ CÁDIZ, Fray D. de: El soldado católico en guerra de religión, Écija, Benito Daza, 1794, p. 14.

62 Ramos, E.: Discurso sobre economía política, Madrid, Joaquín Ibarra, impresor de cámara de S.M., 1769, pp. XVI-XVII. 
cuantas cosas son más curiosas que útiles". ${ }^{63}$ La ciencia se integra así en la narración de las hazañas del militar ilustrado:

Yo le veo adelantar entre rayos cruzados, despedidos al parecer en un día de furor del alto Olimpo, llegar a un punto combatido por todas partes de la muerte; formar una batería, y arreglar sabiamente sus comunicaciones. Yo le veo sondear una laguna, llenando con su intrepidez de asombro a los más animosos y atrevidos; reconocer y medir los varios escarpados y grutas de la montaña, y olvidarse enteramente de sí mismo por servir a su Rey y a su Nación, a pesar de la sangre que brotan sus heridas. Yo le veo finalmente aplicar su exquisita teoría a los hechos, rectificando sus ideas sublimes con la experiencia de los riesgos, y preparándose aquella superioridad, que es la única que concede el derecho de mandar en las batallas. ${ }^{64}$

En su elogio del capitán general Antonio Ricardos, el marqués de Almenara reconocía la pobre educación recibida por el militar en su infancia. Sin embargo, se acometía esa carencia de su homenajeado desde un punto de vista ilustrado. De un lado, esa falta de formación reglada libró a Ricardos de una "educación errónea". Almenara critica el sistema educativo del país mostrando su alivio porque el militar estuviese al margen del "edificio gótico" y las "nociones equivocadas, o inútiles, o dañosas". Por el otro lado, Ricardos habría compensado esa falta con una formación casi autodidacta, aprovechando los momentos de paz para estudiar matemáticas, astronomía, historia, política, moral e idiomas. ${ }^{65}$

A finales de siglo, la imagen del ejército como colectivo promotor de la Ilustración se había consolidado tras décadas en las que los oficiales habían participado en expediciones científicas y viajes pensionados por Europa, habían entrado a formar parte de las Academias y las Sociedades de Amigos del País, y habían tomado la pluma para participar en las reformas internas de la milicia. Esto llevó a Foronda a afirmar en 1781 (en su traducción de las Instituciones de Bielfeld) "que más sabe en el día un cadete que un coronel de los de ahora cincuenta años". ${ }^{66}$ Por su parte, Alfonso Tabares negaba la tradicional imagen de la milicia como "asilo de ignorancia", presentando al oficial como ejemplo de buen soldado, instruido gracias a sus lecturas, sus viajes y su honorabilidad. ${ }^{67}$ Ciertos logros incuestionables y un evidente deseo de halagar al poder se conjugan en estas afirmaciones.

\section{Poder civil, poder militar}

Como es sabido, la dinastía borbónica fomentó la militarización del entramado administrativo de la monarquía. Esta política, aunque fue particularmente acusada en

63 Hernández de Morejón, op. cit. (nota 40), pp. 9-10.

64 Ibidem, pp. 31-33.

${ }_{65}$ Almenara, J. Martínez de Hervás, Marqués de: Elogio del... Señor D. Antonio Ricardos Carrillo de Albornoz, Capitán General de los reales ejércitos y del Principado de Cataluña, general en Jefe del Ejército del Rosellón..., Madrid, Sancha, 1795, pp. 2-5.

66 Bielfeld, Barón de: Instituciones políticas, obra en que se trata de los Reinos de Portugal y España ..., Burdeos, Francisco Mor, 1781, pp. 133-134.

67 TABARES, A.: "Discurso panegírico de la profesión militar y del superior mérito que adquirieron los españoles en las operaciones contra la plaza de Gibraltar", Memorial Literario, XIV, 1788, pp. 178-190, 353-356 y 188. 
los reinos conquistados y afectados por los Decretos de Nueva Planta ${ }^{68}$, se puso en práctica en todo el país, haciendo del ejército un elemento de control del orden público.

Así, lejos de ser un estamento independiente, el ejército borbónico fue un instrumento en manos del poder civil, cuyo control optimizó la monarquía en el siglo XVIII al arrogarse el monopolio de los nombramientos de la oficialidad y de los cargos administrativos (intendentes), dependientes de la secretarías de Guerra y de Marina, multiplicando "las posibilidades de usar la palanca militar para fines que más tenían que ver con la defensa de las posiciones del soberano dentro del reino que con la defensa del mismo frente al exterior".${ }^{69} \mathrm{El}$ incipiente Estado borbónico luchó denodadamente por centralizar todos sus recursos al servicio de la monarquía absoluta, entre ellos a un ejército de súbditos dirigido por nobles. Tal y como ha expuesto Francisco Andújar, "era tal el grado de 'subordinación' de los militares-nobles-político-administradores al poder real que tiene escaso contenido justificar la presencia de un 'poder militar' en el seno del Estado diferenciado del 'poder civil'", ${ }^{70}$

Del militar se espera a la vez un compromiso civil, es decir, que no reduzca su ámbito de acción a la guerra, sino que sea útil al Estado también en tiempos de paz. En otros tiempos, escribía Vargas Ponce, "el militar generoso creía satisfecho su deber con el espontáneo sacrificio de su vida por la seguridad de los otros, derramar sereno su sangre y requerir brioso su pronta espada para verter la sangre enemiga era el único objeto de su gloria y de su deseo"; pero las luces habían demostrado al militar "que también tenía una existencia civil". 71 "¿Acaso [preguntaba el marqués de Almenara] por ser militares dejáis de ser hijos, hermanos, padres y ciudadanos?". ${ }^{72}$ La realidad demuestra que cualquier separación tajante entre la esfera militar y la civil sería artificial puesto que los militares y marinos, como ya se ha dicho, participaron en el mundo intelectual y social de su época. La íntima amistad de Cadalso y Meléndez Valdés es bastante ilustrativa al respecto.

Con esto, no estamos negando una identidad castrense, ni mucho menos. Aunque, políticamente, el ejército acrecentase su vinculación al aparato administrativo, a nivel social, el siglo XVIII desarrolló en el ejército "el espíritu de cuerpo, la conciencia de tener intereses comunes". ${ }^{73}$ En la tensa lucha mantenida entre

68 Molas, P.: "Militares y togados en la Valencia borbónica", en Molas, P. y otros (eds.): Historia social de la administración española, Barcelona, Institución Milá y Fontanals, 1980, pp. 165-181; PÉrez SAMPER, Ma . Á.: "Magistrados y capitanes generales. Civilismo frente a militarismo en Cataluña a finales del siglo XVIII", en Castellano, J. L. (ed.): Sociedad, Administración y Poder en la España del Antiguo Régimen, Granada, Universidad de Granada, 1996, pp. 315-338.

69 Dedieu, J.-P.: "Lo militar y la Monarquía. Con especial referencia al siglo XVIII", en JimÉnez Estrella, A. y AndúJAR CASTILlo, F.: Los nervios de la guerra. Estudios sociales sobre el ejército de la Monarquía Hispánica (S. XVI-XVIII), Granada, Comares, 2007, pp. 231-249.

70 AndúJar CASTillo, F.: "Poder militar y poder civil en la España del siglo XVIII. Reflexiones para un debate", Melanges de la Casa de Velázquez, 28-2 (1992), pp. 55-70 y 69. Ni siquiera el siglo XIX, famoso por sus pronunciamientos, permite hablar de independencia del poder militar. El intervencionismo del sable, como argumenta el profesor Cepeda Gómez, siempre se produjo en nombre del poder civil y no del propio ejército. Así, los sucesos del siglo XX no deben "contaminar" nuestra percepción de los pronunciamientos decimonónicos, en los que el poder militar fue el brazo armado del civil. CEPEDA GóMEz, J.: El ejército en la politica española, 1787-1843, Madrid, FUE, 1990.

71 Vargas Ponce, José: Importancia de la Historia de la Marina española. Precisión de que se confie a un marino y plan y miras con que de orden superior la emprende..., Madrid, Imprenta Real, 1807, p. 2.

72 Almenara, op. cit. (nota 65), p. 5.

73 Domínguez Ortiz, A.: La sociedad española en el siglo XVIII, Madrid, CSIC, 1955, p. 381. 
golillas y arandistas (que ya tienen la apariencia de un "partido militar" a decir de Domínguez Ortiz), podemos apreciar la existencia de una postura civil y otra militar.

Dos ejemplos de la época, que afectaron a sendos oficiales generales como Ricardos y Aranda, nos acompañarán en las próximas líneas. El primero de ellos es un caso de archivo que puede adentrarnos en la existencia de esa cierta dualidad civil/ militar. El 4 de febrero de 1786, el consejero de guerra Francisco Pérez de Lema, un golilla que había hecho carrera como oficial en las secretarías de Despacho ${ }^{74}$, escribió a su "amigo" y protector Floridablanca para hacerle partícipe de la inquina con la que lo miraban los consejeros de espada. El togado buscaba la solidaridad y la complicidad de Moñino - que llevaba años lidiando con la nobleza tradicional "antigolillista"- desde la primera frase del escrito; no sabía ni cómo empezar la carta "cuando voy a tratar de mi Consejo estando V.E. tan harto del suyo". ${ }^{75}$

La sesión del día anterior se había torcido desde el principio cuando se leyó la decisión regia de darle la razón a Lema en su voto a favor de que se equiparasen los castigos a la tropa tanto en tierra como embarcada. El consejero puedo percibir en al ambiente y en el "triste silencio" guardado por los militares la indignación que a estos les causaba que "un covachuelo inserto en golilla les diese reglas".

El siguiente asunto del orden del día era el caso de Agustín Morales, soldado del regimiento de Guadalajara, quien tras haber sido castigado por haber llegado tarde a la lectura de la lista, había blasfemado, en estado de ebriedad, contra la virgen. Al oírle su sargento segundo, fue a castigarlo violentamente y el soldado se defendió agrediendo a su vez a su superior. ${ }^{76}$ Un consejo de oficiales lo había condenado a muerte, pero un asesor había apelado al Consejo considerando que la condena era excesiva de acuerdo a la ley, pero a falta de la opinión de los consejeros, los dos fiscales del Consejo estaban a favor de la ejecución del procesado.

Lema hizo un largo alegato para que Morales escapase del trance con una pena de seis años de presidio. Consideraba que la ordenanza aplicada era errónea pues la diferencia de rango de Morales con su superior era pequeña y que la borrachera y la agresión previa eran atenuantes. En opinión del golilla, un superior que agredía a un inferior quedaba automáticamente desprovisto de su rango. En términos más humanos que legales, apelaba a la empatía de los presentes para que se pusieran en lugar del reo y lo juzgasen "como nosotros quisiéramos que nos juzgasen si fuésemos soldados". Desde su punto de vista, era a todas luces excesivo que la justicia militar aplicase la pena máxima "por un exceso que entre las manos de la justicia ordinaria apenas sería castigado con ocho días de cárcel". Opinaba Lema que el fiscal togado se había dejado llevar por su "celo por el honor de la Virgen" y había querido hacer de aquel "miserable" una "víctima para el escarnio público", añadiendo: "Soséguese pues el Señor Fiscal seguro de que la Virgen no se dará por ofendida de las palabras de un hombre delirante que no ha estado notado de semejante vicio de blasfemo". ${ }^{77}$

De nada sirvieron las palabras del Lema puesto que los consejeros refrendaron la condena a muerte y pidieron que se reprendiera al asesor que la había suspen-

Fichoz, n ${ }^{\circ} 001977$.

AHN, Estado, leg. 4.818.

76 Casualmente, un año antes se había publicado una obra de ficción que representaba un caso similar. En ella, el cabo de Brochard es condenado a muerte por agredir a su sargento, que le había estado provocando y ultrajado previamente. CAlzadA, B. M. (trad.): La subordinación: tragicomedia en cinco actos, Madrid, Ibarra, 1785.

77 AHN, Estado, leg. 4.818. 
dido. Tanto Lema como otros dos consejeros togados se opusieron a la represalia contra el asesor, pero "los legos [esto es, los militares] dieron ley a los letrados".

A corto plazo, Pérez de Lema pedía que Floridablanca detuviese la represión al asesor para que no se cerrase la puerta a la interpretación de las ordenanzas y se pudiese poner algún freno al "despotismo de los militares"; pero dejaba caer ideas de mayor calado, como que casos de este tipo fueran meramente consultivos para que el Consejo no tuviese la última palabra, o que se reformasen las ordenanzas militares.

El caso del soldado Morales es uno de los muchos ejemplos a los que podríamos recurrir para reflejar el hecho de que, de forma paralela al enfrentamiento entre los nobles titulados de mérito y los de sangre, existían rencillas entre ellos en su respectiva vertiente de servidores militares y civiles del rey. En una clara retórica de "ellos y nosotros", de civiles y militares, Lema acusaba a los segundos doblemente por "el rigor con que tratan a la tropa cuando ofende un ápice de sus preeminencias y la blandura con que la tratan cuando atropellan [a] los vasallos del rey", un vicio corporativista ya denunciado por Cadalso. ${ }^{78}$

Así, el enfrentamiento personificado por Floridablanca y Aranda, debió extenderse al resto de órganos de gobierno. Lema cuenta que Ricardos "volvió a insultarle (...) diciendo que me había metido a defender al reo contra lo que debía". Pero, según cuenta el mismo togado, no se arredró y puso al general "como un trapo", aunque sin perder los papeles, dejándolo callado "como un puto". ${ }^{79}$

El segundo ejemplo de los anunciados para reflejar la dualidad entre lo civil y lo militar nos lleva hasta la conocida polémica desatada por el decreto de 16 de mayo de 1788, por el que Carlos III extendió el título de Excelencia, debido a los capitanes generales, a otros puestos y honores (como el de consejero de Estado, arzobispo de Toledo, caballero del Toisón y miembro de la Orden de Carlos III); un episodio que volvió a manifestar el sentimiento de cuerpo del ejército, así como el enfrentamiento del "partido militar" con Floridablanca y los suyos.

En su Memorial al rey, el conde de Aranda expuso la importancia del honor en el ejército y lo poco aconsejable que era privar a la carrera de las armas de esa motivación. Para el aristócrata, el "servicio militar" era diferente a cualquier otro oficio, pues se trataba de un colectivo que acogía "desde la Real Sangre hasta el paisano más pobre", siendo la cuna del ennoblecimiento de un país. El ejército era un cuerpo diferente y debía tener honores distintos de los "corbatas", las carreras "civiles y políticas". ${ }^{80}$

Más interesante, por su tono mucho más directo, es el recordatorio que Aranda -al no haber obtenido respuesta de su Memorial- mandó en agosto de 1788 al secretario del despacho de Guerra, Jerónimo Caballero. Aranda se dirigió a Caballero con su conocida franqueza, sustentada desde el inicio en la condición militar de ambos. La camaradería y la hombría de bien ${ }^{81}$ sustituían así la Grandeza de España de uno y al cargo ministerial del otro:

CADALSO, J.: El buen militar a la violeta, Sevilla, Imprenta de la Ciudad, 1790, p. XI.

AHN, Estado, leg. 4.818.

80 ARANDA, conde de: Memorial del conde de Aranda a Su Majestad sobre las quejas del ejército por los Reales Decretos en que se extendían los mayores honores militares a los campos pacificos del Estado. Madrid, 27 de mayo de 1788, BN, Ms. 7.166.

81 Recordemos las palabras de Nuño al marroquí Ben-Beley: "Según las noticias que Gazel me ha dado de ti, sé que eres un hombre de bien que vives en África, y según las que te habrá dado él mismo de mí, sabrás que soy un hombre de bien que vivo en Europa. No creo que se necesite más requisito para que formemos el uno del otro un muto buen concepto. Nos estimamos sin conocernos; por poco que nos tratáramos, seríamos amigos". CADALSO, J.: op. cit. (nota 42), carta XLII, p. 144. 
Somos coetáneos en el servicio; nuestras primeras armas empezaron en las mismas ocasiones, y con los propios jefes; yo he entendido siempre alabar la buena espada y la probidad de VE, me lisonjeo que de mí también habrá oído no haberme olido mal la pólvora y una hombría de bien sin faramallas. Es V.E. el conducto y voz del Rey para la milicia; yo soy el primer cabo de ella y como tal su orador, con que vamos al asunto. ${ }^{82}$

Los argumentos de Aranda son los mismos que en el Memorial, pero su exposición es mucho más gráfica (¿era justo que los militares cediesen un honor que le era propio? ¿Acaso los arzobispos iban a tocar las campanas por ellos?). El aristócrata exponía abiertamente sus sospechas de que tamaño atropello a los privilegios militares no había podido salir de Carlos III:

Sentaré por principio mío que si me pusieren un cañón al pecho y me dijesen: "si no confiesas que crees que este ha sido primero y original pensamiento del rey, se dispara y te hará pedazos", respondería yo con la mayor frescura y conformidad: "pues que tiren". ${ }^{83}$

La señalada por el aragonés como culpable (siguiendo la voz de esa "opinión general" y ese "público" a los que tanto solía recurrir) era su odiada Junta de Estado, la que consideraba deslegitimada para decidir en un asunto en el que era juez y parte; la misma que conseguiría disolver pocos años después cuando sustituyó a Floridablanca como secretario de Estado.

\title{
4. Soldado católico, soldado patriota
}

\author{
“...la vida de un ciudadano, más que suya, es de la patria”. \\ Caballero de Brucourt: Ensayo sobre la educación de la nobleza, traducido por \\ Bernardo María de la Calzada, 1792. ${ }^{84}$
}

Decir que la religión no fue un factor fundamental en el mensaje legitimador y fidelizador del ejército borbónico, e incluso de la vida cotidiana de muchos de sus miembros $^{85}$, sería sobrevalorar con creces la Ilustración española. Efectivamente, los tratados sobre moral militar se basaron principalmente en la idea de miles christianus, mientras que sobre el terreno, los nuevos capellanes militares intentaban instaurar unas "pautas de conducta cristiana" (moderación, honestidad, subordinación...) que mitigase el impacto de las tropas sobre la población y acentuase la fidelidad de las fuerzas armadas a su monarca. ${ }^{86}$ En el contexto de la cruzada contra los revolucionarios franceses, Fray Diego de Cádiz defendería incluso la conveniencia de un acto

82 Recuerdo del señor conde de Aranda al Ministro de la Guerra en 25 de julio de 1788..., BN, Ms. 7.166, ff. 37-38.

83 Ibidem, f. 43.

84 BruCOuRT, Charles François Oliver Rosette, Chevalier de: op. cit. (nota 9), tomo I, p. VII.

85 “...los estudios realizados sobre la religiosidad de los militares (oficiales) en el XVIII no dejan lugar a dudas sobre la permanencia de las prácticas cristianas en el ejército, incluso se puede hablar de una mayor pureza de las mismas conforme nos acercamos a fines de la centuria". García HurTado, op. cit. (nota 17), p. 483. Véase GIL MuÑoz, M.: "Un estudio sobre mentalidades en el ejército del siglo XVIII", Cuadernos de Historia Moderna, 10 (1989-1990), pp. 121-146.

86 García Hurtado, op. cit. (nota 17), pp. 423-485. 
de consagración del soldado católico ${ }^{87}$; y Clemente Peñalosa escribiría poco después que "la religión sola forma héroes perfectos" puesto que "las virtudes que constituyen el honor militar son ficticias sin la religión". ${ }^{88}$ La propia monarquía, falta de armas ideológicas para movilizar y fidelizar a la soldadesca, quiso fomentar la idea de soldado católico y no dejó de encomendarse a la protección divina, como prueban las rogativas ordenadas por Carlos III antes del bombardeo de Argel.

El gran interés demostrado por la monarquía borbónica en politizar el mensaje de obediencia transmitido por la Iglesia, en aras de hacerlo más concreto a sus necesidades de gobierno ${ }^{89}$, dio lugar a una obra en la que merece la pena detenerse: la Instrucción militar christiana para el ejército y la armada de $S . M .{ }^{90}$ Nos interesa especialmente la edición de 1788, a cargo del artillero Vicente de los Ríos y publicada de orden del rey con la intención de sacar el texto del ámbito de la academia de Artillería de Segovia para extenderla a todas las fuerzas armadas de la Monarquía. Respecto a las obras del siglo XVI, que ponían el acento en el aspecto religioso, esta Instrucción, igual que otras de la época, lo pone en el militar. Se puede decir que "se está operando un cambio desde la obra de devoción a un código deontológico de conducta militar"91; la fe católica no hace sino ungir y sancionar el servicio al monarca. ${ }^{92}$

Para el rey, según el prólogo, la práctica de una "sana doctrina católica (...) constituye el verdadero honor del militar perfecto". El hombre de bien se asocia al buen cristiano, que además de ser creyente se comporta como un buen súbdito y ciudadano, que paga sus deudas, nunca "agravia a su familia, a su patria y a su Soberano", cumple con sus obligaciones y huye del ocio y la disipación, etc., pues todo ello está vinculado a su salvación. ${ }^{93}$ La Instrucción obliga "en conciencia" al oficial a cumplir su cometido, que incluye la instrucción en "el arte militar". Por su parte, el soldado "debe ser fiel a su rey y a su patria, respetar a cualquier oficial" y comportarse como es debido. ${ }^{94}$

Las virtudes propias de un militar quedan resumidas en cuatro: "la subordinación, la fortaleza, el amor de la disciplina militar y el celo patriótico". ${ }^{95} \mathrm{La}$ falta de subordinación hace caer en pecado mortal al militar que incurre en ella. En cuanto a la patria, morir por ella "es una acción tan gloriosa como cristiana", una fidelidad extensible al monarca puesto que, el monarca no es solo el representante de Dios en la tierra, sino que además su gloria "ilustra toda la nación". ${ }^{96}$

El militar está así supeditado a un bien superior, el de la patria y el rey, respaldado por la religión y que trasciende su propia individualidad. Un interesante pasaje deja la puerta abierta a que el soldado busque su propia gloria pero siempre "con tal que

87 CÁdiz, op. cit. (nota 61), p. 78 y ss.

88 PeÑalosa, op. cit. (nota 34), p. 178.

89 Calvo Maturana, A.: “Aquel que manda las conciencias...”: Iglesia y adoctrinamiento politico en la Monarquía Hispánica preconstitucional (1780-1808), Cádiz, Ayuntamiento de Cádiz, 2011.

90 Madrid, Pedro Marín, 1788. Se trata de una obra francesa de 1727 traducida al castellano en 1732 y que conoció cinco ediciones en España. En 1774, Vicente de los Ríos volvería a traducirlas. Esta traducción es la reeditada en 1788. García HurTado, op. cit. (nota 17), pp. 434-435.

$91 \quad$ Ibidem, p. 436.

92 A pesar de matar a su prójimo, el militar no solo puede salvarse sino que puede ser santo si cumple con la labor que Dios le ha encomendado en la tierra. Instrucción militar.., op. cit. (nota 90), pp. 6-12.

93 Ibidem, pp. 1-5. La deserción, la violencia con los compañeros, el abuso de la población civil (con mención expresa a la inmoralidad de la "rapiña") y la indisciplina (blasfemia, embriaguez, juego, torpeza o "amor impuro", duelo, etc.) son doblemente censurados a ojos de Dios y del rey.

94 Ibidem, pp. 12-15.

95 Ibidem, p. 53.

$96 \quad$ Ibidem, p. 68. 
no sacrifique el bien del Estado a su gloria particular, y que nada le interese más que su salvación", 97

El papel de la patria como vínculo entre el rey y sus súbditos es un tema fundamental que nos ocupará en las próximas páginas. La obediencia al rey por mandato divino pudo ser el mensaje transmitido a la mayoría de la población, pero no el monopolístico. La Corona necesitaba crear nuevos lazos entre su causa y la de la élite para ganarse su adhesión. En figuras como la de Cadalso, irreverente y anticlerical en su correspondencia, y patentemente vinculado con los conceptos de patria y nación en sus Cartas $\mathrm{Ma}$ rruecas, observamos una concepción instrumental del mensaje religioso, como ocurre en su famosa defensa del mito de Santiago en la carta LXXXVII de la obra citada.

Incluso en religiosos como Antonio Eximeno encontramos rastros evidentes de un mensaje ajeno a los tiempos barrocos. Este autor insertaba la fundación de la Academia de Artillería de Segovia en la narrativa científica de la época, mencionando elogiosamente a Descartes, Galileo y Newton entre otros; participando de la narrativa de científica de progreso al afirmar que "cada siglo muda de rumbo para buscar la verdad, y la única que al fin halla es que el siglo antecedente erró". ${ }^{98}$

Años después, ya como exjesuita, Eximeno alcanzaría el pragmatismo absoluto al afirmar que lo fundamental para que un ejército funcione es el buen hacer de quienes lo dirigen. De nada servía en su opinión lo "que en el nuevo vocabulario se llama patriotismo" (que el autor reconoce más implantado en Francia que en España) sino para aumentar el alistamiento de soldados para carne de cañón. Pero aún menos influjo otorgaría, sorprendentemente, a la religión, "en la cual, durante el calor de la batalla ninguno de los combatientes piensa". ${ }^{99}$

Afirmaciones como la anterior son extraordinarias, pero se puede localizar en las fuentes de la época una narrativa no religiosa vinculada al ejército. En el elogio de Urrutia, escrito por un clérigo como Sebastián Hernández de Morejón, Dios y la religión no aparecen prácticamente hasta el final del relato, cuando el héroe encara su muerte. En el texto, Dios es mencionado una sola vez, y podemos encontrar la palabra "religión" en solo 4 ocasiones (ninguna la palabra "católico"). En cambio, "patria" se puede encontrar 26 veces (más las 4 de "patriotismo") y "nación", 11. Por otra parte, la suma de "rey", "soberano", "monarca/s", "monarquía", "trono", "Carlos III" y "Carlos IV" ofrece un total de 34. El papel secundario de la religión a favor de la patria y el rey en el texto es evidente. ${ }^{100}$

En la retórica dieciochesca, al menos la dirigida a las élites (como era el caso de la oficialidad), Dios adquiere un papel honorífico que deja paso a dos elementos fidelizadores terrenos e interrelacionados que encontramos en los consejos de Fernán Núñez a sus hijos: "Vuestro rey y vuestra Patria, cuyos intereses son unos mismos, deben ser, después de Dios, el primer objeto de vuestra atención y cuidado". El aristócrata, militar y diplomático trasladaba a sus herederos la importancia del "espíritu patriótico" y la obligación divina de derramar hasta la "última gota" de su sangre por "la Nación y el Soberano". ${ }^{101}$ Otro noble y militar, el marqués de Alós, dejaría a sus

Ibidem, pp. 71-72.

EXIMENO, op. cit. (nota 16), p. 3.

99 Eximeno, A.: "Disertación sobre el valor militar en defensa de la religión cristiana", en El espíritu de Maquiavelo..., Valencia, Benito Monfort, 1799, pp. 70-95 y 93-94.

100 Hernández de Morejón, op. cit. (nota 40).

101 Fernán NúÑez, conde de: Carta de Don Carlos de los Ríos, XXII Señor y VI conde de Fernán Núñez a sus hijos, París, Pedro Didot, 1791, pp. 6-9. 
hijos una narración de sus servicios a Felipe V a modo de instrucciones para "formar vasallos útiles al rey y a la patria". ${ }^{102}$

El rey, claro está, ocupa un lugar privilegiado en este desplazamiento. Antes que de la patria, el ejército es del soberano. De Jorge Juan, Bails escribió que "tenía una patria, tenía un soberano", y que "primero que religioso era vasallo". ${ }^{103}$ Vicente de los Ríos recordaba a los cadetes que la instrucción recibida los vinculaba aún más a su rey:

Todos somos deudores a la liberalidad y magnificencia del Rey: todos debemos esmerarnos en su servicio, y desempeñarlo con nuestras vigilias, nuestro sudor, nuestra sangre; pero en nadie es mayor esta obligación que en aquellos, que a más del respeto de vasallos, le son deudores también de la crianza, de la instrucción, del adelantamiento y aun del sustento. Vosotros sois, ilustres Jóvenes, a quienes el nacimiento, el destino y la gratitud obligan a no tener otro objeto gravado y fijo en vuestros pechos, sino la heroica imagen de Carlos Tercero. ${ }^{104}$

Alfonso Tabares rechazaba los rumores y críticas surgidos tras el fracaso del sitio del último sitio de Gibraltar, estimando que solo el soberano estaba capacitado para juzgar la conducta del ejército porque él sabía mejor que nadie "que el oficial sacrifica su vida y bienes por la patria". ${ }^{105}$

La patria es junto al rey y Dios, la tercera pieza de este puzle de fidelidades. Pablo Fernández Albadalejo ha estudiado el "nuevo arte de reinar" de la monarquía dieciochesca, cómo los Borbones tendieron a representarse como padres de la patria, primero, y reyes patriotas, después, y establecieron un vínculo afectivo con la comunidad a través de la patria y un compromiso con el bien público. ${ }^{106}$ Este nexo sentimental se puede encontrar ya, aunque de nuevo en forma embrionaria ${ }^{107}$, en la publicística de la primera mitad de siglo. Según el Elogio histórico del marqués de Villena, este, tras haber fallecido dos miembros de su regimiento en la batalla de Camposanto, "se le oyó decir con una presencia de ánimo admirable envidiar la suerte de estos dos bizarros oficiales, que habían sacrificado sus vidas por la Patria y por la justa causa del rey". ${ }^{108} \mathrm{El}$ dualismo patria/rey, en el que normalmente la patria siente o padece y el monarca actúa y vela por su bien ${ }^{109}$, es habitual. Leemos en el elogio de Urrutia, que era "querido de su rey, adorado de la patria". ${ }^{110}$ En la famosa carta de Morla al almirante Keith, el primero advierte que si persiste en su idea de

102 Alós, marqués de: Carta, instrucciones y relación de servicios que el Exmo. Señor Don Antonio de Alós y Rius, marqués de Alós (...) escribió a sus hijos..., Palma, 1767, p. I (obra reeditada en 1800).

103 BaILs, op. cit. (nota 13), p. 3.

104 Ríos, op. cit. (nota 56), pp. 38-39.

105 TABARES, op. cit. (nota 67), p. 359.

106 Fernández Albadalejo, P.: "Dinastía y comunidad política: el momento de la patria”, en Fernández Albadalejo, P. (ed.): Los Borbones. Dinastía y memoria de una nación, Madrid, Marcial Pons, Casa de Velázquez, 2002, pp. 485-532.

107 Las Ordenanzas de 1768 aún hablaban de "patria” para referirse a la región de procedencia de cada militar (por ejemplo, "andaluz").

108 Angulo, F. A. de: Elogio histórico del Excelentísimo Señor D. Juan López Pacheco, marqués de Villena..., Madrid, Imprenta de la Academia, 1751, p. 11.

109 En relación a Urrutia, "la Patria miraba con sentimiento ausente de sus brazos a un hijo [que cumplía una misión en América]" y "el monarca español, justo apreciador del mérito había ya prevenido con sabia providencia los deseos de sus vasallos [para traerlo de vuelta]". Ibidem, pp. 24-25.

110 Hernández de Morejón, op. cit. (nota 40), p. 67. 
atacar Cádiz a pesar de la epidemia "hallará la defensa que corresponde al honor de mi nación y al decoro de mi Soberano". ${ }^{111}$

El rey y el reino 112 ("nación" para los autores ilustrados) son dos sujetos diferenciados cuyos intereses podían no ser los mismos. Para el marino Vargas Ponce (y para Cadalso en la III de sus Cartas Marruecas), Carlos V había sido un rey más preocupado por lo patrimonial que por lo nacional, olvidando "la primera máxima de todo buen príncipe (...) que sus vasallos son su verdadera casa y familia". ${ }^{113}$ Afortunadamente, al menos eso escribía Vargas Ponce cara al público, la dinastía borbónica había unificado los intereses de la Corona y los de los españoles. El "padre de los Borbones", Felipe V, lo fue también "de sus vasallos, reengendrando la española gente" y sus descendientes supieron que "no hay otro medio para hacer feliz a una nación que ilustrarla". ${ }^{114}$

No obstante, se pueden encontrar relatos en los que el monarca ya tiene un papel sorprendentemente secundario en detrimento de la nación. Es el caso de la ya mencionada Historia de la milicia española de Joaquín María Mendoza (1776), que habla de España y de la nación retrotrayéndolas a tiempos remotos, en unos términos continuistas propios de un Modesto Lafuente. También es protagonista la nación en el Discurso sobre la economía politica del militar Enrique Ramos (1769) quien sí que reconoce los desvelos de la dinastía borbónica por ella.

En el recién mencionado texto de Vargas Ponce, los Borbones pasan a un segundo plano una vez sembrada la semilla de la ilustración y el patriotismo. Este autor reflejaba las nuevas necesidades de la Monarquía, que ya no se limitaban a una obediencia ciega al rey absoluto, sino que requerían la participación de los súbditos en un proyecto reformista que debían entender como común:

De las ventajas que la ilustración de nuestra era, nos proporciona es haber descubierto y multiplicado las relaciones recíprocas que unen a los hombres entre sí y a todos con la sociedad, haber dado a conocer la mutua dependencia, de los eslabones que constituyen la compuesta cadena de una nación, y haber puesto a benéfica y clara luz las comunes obligaciones de sus individuos. En siglos de menor sabiduría, no tan notorios estos íntimos enlaces, trabajaba cada uno impulsado por la ley primaria del contrato social a la conservación de un todo en que era comprehendido. ${ }^{115}$

Un militar, Enrique Ramos, repasaría la historia de España en clave patriótica. En su visión de la Reconquista no pesa el factor religioso sino "el nombre de la patria, que sin cesar sonaba en las bocas de todos y era el punto en que se reunían en cualquier desavenencia". ${ }^{116}$ Los deberes con la patria, la sangre derramada por ella y el heroísmo están también muy presentes en el vocabulario de La subordinación,

111 Cit. por Herrero Fernández-Quesada, op. cit. (nota 3), p. 853.

112 Cepeda Gómez, J.: "Servir al Rey y servir a la Nación. Ilustrados, liberales y el deber militar", Cuadernos de Historia Moderna, 16 (1995), pp. 139-156.

113 Vargas Ponce, J.: Discurso leído a la Sociedad Matritense de los Amigos del País sobre la serie de sucesos que originaron estos establecimientos, y las ventajas que proporcionan, en junta pública para la distribución de premios, Madrid, Sancha, 1790, p. 12.

114 Ibidem, pp. 23-26.

115 VARgas Ponce, op. cit. (nota 71), p. 1.

116 Ramos, E. (pseudónimo Antonio Muñoz): Discurso sobre economía política, Madrid, Joaquín Ibarra, impresor de cámara de S.M., 1769, p. 7. 
tragicomedia alemana traducida del francés por Bernardo María de la Calzada. ${ }^{117}$ El ejército es más que un sustento o una empresa privada del rey. Benito Bails diferenciaba a los militares de vocación de los que entraban a servicio forzados, pretendiendo los padres dar "acomodo" a sus hijos "y no defensores a la patria". 118

En el seno de una élite cuyas referencias y paradigmas están cambiando la convivencia del militar ilustrado tanto con conceptos de fidelidad vertical (Dios y monarquía) como horizontal (patria, ciudadanía, hombría de bien) está muy presente en los artículos de Manuel Aguirre, "el Militar Ingenuo", en el Correo de Madrid. En el "Rasgo militar" de diciembre de 1787 encontramos el anhelo de morir por la patria (o por Dios y por la patria) y una interesante definición de nación: “¿no es una familia que se extiende al infinito?". ${ }^{119}$ Aunque la adhesión de Aguirre a los Borbones no tenga fisuras ${ }^{120}$, es destacable su insistencia en situar a la patria como el quid de la cuestión y a sus integrantes, los "ciudadanos" y "conciudadanos" (sin soberanía ${ }^{121}$, pero ni súbditos ni vasallos) como lectores del periódico y protagonistas (con el apoyo y la anuencia, eso sí, de un rey, "supremo jefe de la nación", que debe evitar los obstáculos) de la narración. No es baladí que en su discurso para la formación de una sociedad militar, Aguirre definiese a la milicia como "la noble profesión de defender con las armas y con el peligro de la vida los intereses y bienestar de la patria"122 o, en otro artículo, como "un compuesto de ilustres y generosos ciudadanos dispuestos a sacrificarse por las ventajas de su patria". ${ }^{123}$

No es de extrañar que, en 1808, al desaparecer el rey, la nación pugnase por ocupar su lugar soberano y se acelerase el trasvase de fidelidad del monarca a la patria. El propio Morla se dirigiría en mayo de 1808 a los gaditanos como "amados españoles" asegurándoles que "si sois de España, yo de España no me separo, morir o vencer es mi mote". ${ }^{124}$ Al comunicar a la Suprema la victoria de Bailén, el conde de Tilly inicia su carta diciendo que "España, o por mejor decir el ejército de V.A. logró la victoria más completa que de mucho siglos a esta parte ha visto la Nación”. ${ }^{125}$ En 1812, el mariscal Álava daba la oportunidad a los afrancesados de volver "al seno de vuestra amada patria y a la estimación de vuestros compatriotas". ${ }^{126}$

117 Calzada, B. M. (trad.): op. cit. (nota 76).

118 BAILs, op. cit. (nota 13), pp. 10-11.

119 Correo de Madrid, 5/12/1787, p. 588. En un discurso anterior había ofrecido otra definición: “¿Qué es la nación sino el conjunto de todas las poblaciones y gentes que la habitan?”, Correo de Madrid, 53, 25/04/1787.

120 "Nuestra nación fue una de las que tuvieron la dicha de lograr Reyes que merecieron la confianza de todo el uso de la Soberanía, y por consiguiente el poder más ilimitado y la más alta dignidad". "Discurso dirigido a la Real Sociedad Aragonesa", Correo de Madrid, 182, 19/07/1788, pp. 1.075-1.078; 183, 23/07/1788, pp. 1.083-1.085; y 184, 26/97/1788, pp. 1091-1.092.

121 Gordon, D.: Citizens without sovereignty: equality and sociability in French thought, 1670-1789, Princeton, PUP, 1994.

122 Correo de Madrid, 168 (31/05/1788), pp. 963-965 y 169 (4/06/1788), pp. 971-972.

123 En este caso, se trata de una definición de lo que fue el ejército en la Antigüedad y lo que debería volver a ser. "Cartas sobre la milicia", Correo de Madrid, 150, 29/05/1788, pp. 858-864, en Cartas y discursos del Militar Ingenuo en el "Correo de los Ciegos de Madrid”. Edición de Antonio Elorza, San Sebastián, Patronato José María Quadrado, 1974, pp. 287-295. Lo mismo se puede decir de Cadalso, quien escribió en sus Cartas Marruecas que "el ser buen ciudadano es una obligación verdadera de las que contrae el hombre al entrar en la república". CADALSO, J.: op. cit. (nota 42), carta LXX, p. 210).

124 Cit. por Herrero Fernández-Quesada, op. cit. (nota 3), pp. 974-975.

125 Noticia de la victoria de Bailén, 21 de julio de 1808.

126 Álava, M. R. de: "Proclama del Sr. D. Miguel de Álava, mariscal de campo de los reales ejércitos, dirigida a los soldados españoles que están en las banderas del intruso rey Josef", Gazeta de Madrid bajo el Gobierno de la Regencia de las Españas, 1, 17/08/1812, p. 5. 
Este protagonismo de los ciudadanos sin soberanía en el discurso de la monarquía se puede percibir en el renacimiento dieciochesco del ethos heroico. Militares como Cadalso (en las Cartas Marruecas, Nuño decía querer escribir una ejemplificadora "historia heroica de España") y Aguirre defendieron la importancia de la emulación. Según este último, la gesta de las Termópilas fue producto de una sociedad, la espartana, que estaba orientada a la formación de héroes: "sencillez de costumbres, amor del bien público, constancia en despreciar la muerte misma y gusto en sacrificarse por la patria", junto a la asunción de que "no es la vida la que da honor, sino el uso que de ella se hace". ${ }^{127}$

Si el héroe refleja los valores del colectivo que lo ensalza, el héroe neoclásico representa a la vez un desplazamiento en la narrativa oficial del protagonismo del monarca a favor de sus súbditos más fieles y una evidente valorización de las virtudes civiles sobre las militares, del celo reformista de toda una vida sobre las grandes gestas. El héroe es un espejo ejemplar en el que mirarse y no pocas veces es un constructo político, como lo fueron los representados en los elogios fúnebres de finales del XVIII español, que dibujaron una élite fiel al monarca pero sobre todo celosa del bien de la patria y la pública felicidad. ${ }^{128}$

No es de extrañar que las Sociedades Económicas estuviesen a la vanguardia de estas exaltaciones del héroe civil. Los elogios a los miembros fallecidos ${ }^{129} \mathrm{de}$ la matritense son buena prueba de ello. De hecho, Vargas Ponce situaba el nido de la "generosa águila del patriotismo" en la fundación de la Sociedad Vascongada de Amigos del País y estimaba que si algún día el papel de los elogios se hiciese piedra y "dedica[se] estatuas la España a los héroes de un patriotismo puro y desinteresado, te tocará la primera, ilustre Peñaflorida". ${ }^{130}$

Estos valores ciudadanos se pueden apreciar también en los elogios a los militares difuntos. ${ }^{131}$ A decir del panegirista de Urrutia:

La memoria del hombre, que vive para la Patria, debe ser transmitida a los tiempos más remotos por los mismos medios, que es perpetuada la virtud. Si las Pirámides, Columnas y Obeliscos fueron un monumento de inmortalidad para los antiguos, la Filosofía y la Elocuencia han substituido entre nosotros otras señales más nobles, más dignas del mérito y más capaces de hacerle contrarrestar el torrente de los Siglos. El honor singular de un elogio público es una lección eficaz para todas las generaciones, y halla en él el último de los nietos, la pintura agradable de los hechos de sus mayores, y un estímulo poderoso para seguir sus pasos en el camino de la gloria. El aplauso, la admiración y el reconocimiento pasan de este modo de edad en edad, y producen en todas partes la ardiente emulación del heroísmo. ${ }^{132}$

127 "Discurso sobre el verdadero heroísmo", Correo de Madrid, 101 (10 de octubre de 1787), pp. 457-459.

128 Calvo Maturana, op. cit. (nota 6), pp. 112-135.

129 Los héroes son más útiles y menos peligrosos para el poder cuando ya no están en el mundo de los vivos sino en el del recuerdo. El marqués de la Almenara denunciaba que fueron los mismos los que "persiguieron al inmortal Jorge Juan mientras vivía, y que le canonizaron después de muerto". Almenara, op. cit. (nota 65), p. 9.

130 VARgas Ponce, op. cit. (nota 71), p. 92.

131 Ya en 1764, en la inauguración de la Academia de Artillería, Antonio Eximeno aseguraba que Carlos III estaba fundando un "colegio de héroes". EximENo, op. cit. (nota 16), pp. 16-17.

132 Hernández de Morejón, op. cit. (nota 40). 
Por lo general, los tratadistas militares recomendaban a la oficialidad que leyesen libros de Historia. Algo que según Hernández de Morejón hacía Urrutia, quien "al través de los siglos recogía por todas partes las luces que podían ilustrarle". Sin la vida de los grandes hombres, "la patria, entonces esclava de la ignorancia, carecería de genios que la ilustrasen". ${ }^{133}$ Al morir, el héroe pasaba a su vez a la inmortalidad histórica y, por tanto, integraba la nómina de biografías ejemplares e inspiradoras. ${ }^{134}$ Por su parte, el "reconocimiento nacional" a un "bienhechor de la patria" llora la marcha del héroe. De Urrutia se dice que "no hay español que no haya sentido su muerte". 135

En los círculos ilustrados, cuando se ensalzaba a un militar como héroe, se hacía por sus virtudes civiles. ${ }^{136}$ En un Discurso sobre el verdadero heroísmo, publicado en el Correo de Madrid (y presumiblemente escrito por Aguirre), leemos que no son las victorias sino "la virtud en el soldado, ayudada de la fortuna" el camino para "aspirar al heroísmo". Amor por la justicia, beneficencia y humanidad son los rasgos del héroe, los que pocos conquistadores han sido capaces de tener. Los héroes ensalzados en las academias no son populares, puesto que el corazón y el sentir de la élite y el del vulgo no son el mismo. ${ }^{137}$ El marino Martín Fernández de Navarrete menospreciaba "los aplausos del vulgo de la nación" a Barceló, considerando implícitamente a este colectivo como más fácil de engañar y con menos criterio para encumbrar a los héroes; en este caso, el pueblo no era capaz de ver que dicho marino era un ignorante de la vieja escuela. ${ }^{138}$ De parecida opinión era el artillero Vicente de los Ríos al afirmar que "el vulgo, que confunde siempre las ideas más separadas, y remotas, equivoca los Hombres Ilustres con los famosos, y tiene por tales solo a los Conquistadores, cuyos nombres conoce, porque su memoria se divulga, y radica más que la de los Sabio". ${ }^{139}$ Interesante afirmación -y más proviniendo de un militar-a favor de los héroes civiles.

Pero el componente visceral del derramamiento de sangre hace que podamos encontrar también referencias al clásico ejemplo del héroe que muere en el campo de batalla y que es exaltado a la par por la élite y el pueblo, reuniendo a su vez los atributos neoclásicos y románticos. El propio Manuel Aguirre consideraba que un

133 Ibidem, p. 13.

134 “¡Ojalá que la imagen de este Héroe, la memoria de sus servicios, la impresión viva de su gloria siga por todas partes a vuestro genio, le estimule en el reposo, le anime en los combates, le sostenga en las fatigas, le guíe en los peligros, y le inspire el valor, la magnanimidad, el amor generoso y el celo ardiente por la Religión, por el Rey y por la Patria". Ibidem, p. 81.

135 Ibidem, p. 5.

136 Sirvan como ejemplo este sarcástico pasaje de Voltaire: “Cándido, que temblaba como un filósofo, se escondió cuanto pudo durante aquella heroica matanza (...) ancianos acribillados de heridas veían expirar a sus degolladas mujeres con sus hijos en los brazos ensangrentados; allí, doncellas destripadas, después de haber saciado en ellas sus apetencias naturales algunos héroes, exhalaban el postrer suspiro...". VolTAIRE: "Cándido o el optimismo", en Cándido y otros cuentos, Madrid, Alianza, 1974, pp. 55-56.

137 Idea que trasluce de la justificación de Morla para no ejecutar a los prisioneros de la batalla de Bailén: "Por fortuna, solo el populacho más abyecto se separa en esta parte de la generosidad y nobleza del carácter Español. No ofender al rendido, no vengar las injurias en el caído, y perdonar a quien se humilla, son virtudes indelebles en el corazón Español". MorLA, Tomás: Justificación que hace a la Nación Española el capitán general de Andalucía, gobernador de Cádiz, acerca de su conducta con Dupont y demás generales franceses. Cádiz, 6 de Septiembre de 1808, p. 7.

138 Carta a Don Vicente García de la Huerta..., op. cit. (nota 50), p. 112.

139 Ríos, V. de los: Discurso sobre los ilustres autores e inventores de artillería que han florecido en España desde los Reyes Católicos hasta el presente, Madrid, Joaquín Ibarra, 1767, p. 7. 
militar encontraba la gloria al perder la vida al servicio de su patria ${ }^{140}$, idea que seguirá vigente en el ejército liberal. No podemos olvidar que dos artilleros, Daoiz y Velarde, se convertirían en los dos primeros mártires del pensamiento liberal español. En este caso, más que héroes neoclásicos, se trata de héroes románticos, sacrificados en defensa de la patria, que Juan Bautista Arriaza compararía en un himno de 1814 con el Cid, haciendo del cuerpo de artillería (por encargo del mismo, eso sí) un baluarte de la resistencia española. ${ }^{141}$ Esto no difiere de lo dicho hasta ahora sino afirma el tránsito (en un modelo más civil y en otro de corte más militar) del héroe religioso o monárquico al patriótico, ya apreciable en los años 70 del siglo XVIII en autores que, como Cadalso, escribieron que el gran estímulo del héroe es "el patriotismo". ${ }^{142}$

De hecho, antes que a los dos héroes del Dos de mayo, la España dieciochesca rindió tributo a un héroe militar fallecido en combate, como fue Federico Gravina. Previamente, habíamos conocido el homenaje a algún prestigioso militar fallecido por parte de su círculo más cercano, como ocurrió con Cadalso (muerto en acto de servicio en Gibraltar) ${ }^{143}$ o Jorge Juan. ${ }^{144}$ En vida, las supuestas victorias de Barceló en Argel fueron profusamente elogiadas (García de la Huerta, en su complicada relación con lo barroco y lo neoclásico, lo situó entre los "héroes de la patria"145), pero las composiciones poéticas en su honor están alejadas del tono patriótico del que venimos hablando.

Así, podemos considerar a Gravina el primer gran héroe no regio homenajeado por la monarquía absoluta. Si los héroes de los elogios de las Sociedades de Amigos del País presentaban virtudes ciudadanas que fomentaban la ejemplaridad, pero sin alcanzar un protagonismo que pudiese eclipsar al rey y sin salir de las paredes de dichas sociedades, por el contrario, el marino recibió honores de Estado. No sabemos si estos actos fueron consecuencia del proceso del que venimos hablando, un reflejo del ejemplo napoleónico en Francia, la emulación de las noticias de los honores brindados a Nelson, también fallecido en Trafalgar, o una combinación de los tres factores, pero el gobierno de Carlos IV decidió romper su costumbre de silenciar los reveses militares y presentó la batalla de Trafalgar (difícil de ocultar, por otra parte, puesto que se había producido frente a las costas españolas) como una gloriosa derrota; una maniobra publicística que merece la mayor de las atenciones.

140 "De la gloria", en Cartas y discursos del Militar Ingenuo en el "Correo de los Ciegos de Madrid", ed. de Antonio Elorza, San Sebastián, Patronato José María Quadrado, 1974, pp. 227-229.

141 "AL CUERPO DE ARTILLERIA. Gloria al cuerpo, que el primero / Por la boca de un cañón / Respondió a Napoleón / 'Obedecerte no quiero'. / Pues ese incendio guerrero, / Que ya en todas partes arde, / Y aterra al Corso cobarde, / Todo es efecto del rayo / Disparado en dos de Mayo / Por DAOIZ y VELARDE.” ArRIAZA, J. B.: Himno patriótico de D. Juan Bautista Arriaza ..., Madrid, Imprenta Nacional, 1814.

142 CADAlso, J.: op. cit. (nota 42), carta IV, p. 53.

143 Amigos del círculo salmantino de Cadalso como Meléndez e Iglesias de la Casa fueron los únicos que se preocuparon por rendirle homenaje.

144 Por ejemplo, Francisco Rovira dedicó un tratado de artillería a su "inmortal memoria". Considerando "el poderoso estímulo para la imitación en los súbditos" que supone "el ejemplo de los superiores", el autor recordaba cómo Jorge Juan había promovido las ciencias por "el bien del Estado y la gloria de la nación" y lo consideraba "uno de los primeros matemáticos de Europa y de los más elevados ingenios de este siglo". RoviRA, F. X.: Tratado de artillería para el uso de caballeros Guardias-Marinas en su Academia, Cádiz, Imprenta de la Academia, 1773. Ese mismo año, Miguel Sanz publicó una Breve noticia de la vida del marino, reeditada y prologada en 2013 por Armando Arberola y Rosario Die.

145 García de la Huerta, V.: Endecasílabos que con motivo del bombardeo de Argel..., Barcelona, Imprenta de Fulalia Piferrer, 1783, verso 34. 
La imprenta fomentó este fervor patriótico publicando oraciones fúnebres por las víctimas sacrificadas "por el rey y por la patria", como la firmada por el religioso Manuel Fernández Varela quien como "ministro de Jesucristo" y "ciudadano español" llamaba a los fieles a la fortaleza y la constancia ${ }^{146}$; o las Octavas a la batalla ("iOh! si pintar supiese el patriotismo / que bien cada hijo de la patria mía"147). Quintana, Mor de Fuentes y María Rosa de Gálvez entonaron el mismo pesar patriótico. ${ }^{148}$ Una relación escrita en lenguaje popular insinuaba seguir las evidentes preceptivas oficiales ${ }^{149}$ y animaba a los "compatriotas" anticipando una pronta revancha. La Gaceta de Madrid informó del enfrentamiento (a través de los reportes de Gravina), anunció obras sobre el particular y se hizo eco de la reacción de los españoles en clave nacional. Por ejemplo, en noviembre hablaba del patriotismo de los bilbaínos que habían abierto una suscripción en favor de los vizcaínos fallecidos en el combate. ${ }^{150}$ Antes, el 12 de noviembre, el mismo periódico había publicado una carta de Godoy comunicando los deseos del rey de premiar "la heroicidad y valor" de los embarcados en la escuadra de Gravina; una medida, leemos,

digna de un Rey tan grande como el que nos gobierna y justa memoria para que en todas clases y destinos sepan sus felices vasallos que si vierten su sangre en el campo del honor, tienen un rey piadoso que atiende a sus familias y tan justiciero que premia las acciones con mano franca.

Entre los ascensos encontramos el de Gravina a capitán general. ${ }^{151}$

También publicó la Gaceta la noticia de la muerte de Gravina semanas más tarde, el 9 de marzo de 1806, como consecuencia de sus heridas. El obituario exaltaba su mérito y su heroísmo, igual que lo había hecho Carlos IV en la correspondencia mantenida con él poco antes de morir. ${ }^{152} \mathrm{~A}$ partir de entonces, el periódico publicitó la venta de retratos del personaje y de oraciones fúnebres en su honor. La pronunciada por Pedro Gómez Blanco comparaba a Gravina con Nelson ("Lloren los ingleses cuanto quieran la pérdida de su héroe; nosotros lloraremos siempre la del nuestro") y exaltaba a sus compatriotas a imitar al marino en su celo al servicio de Dios, la patria y el rey. ${ }^{153}$ Por su parte, el elogio firmado por Mor de Fuentes hacía un extenso repaso de la larga hoja de servicios del marino a la marina del rey.

Décadas después, en 1830, un artillero, el teniente general conde de Casa Sarría, se encargó del discurso de reapertura de la Academia de Artillería de Alcalá de Henares, cerrada en 1823 por la alineación de sus miembros a favor del gobierno

\footnotetext{
146 Fernández Varela, M.: Oración fúnebre..., Madrid, hija de Ibarra, 1806, pp. 5-6.

147 Octavas a la batalla naval del día 21 de octubre de 1805 a la vista de Cádiz, entre la escuadra inglesa y la combinada de Francia y España, Cádiz, Casa de Misericordia, 1805.

148 Calvo Maturana, op. cit. (nota 6), pp. 131-135.

149 "Supuesto que en el diario / Nos convida y alborotan / A escribir sobre el combate, / Bien sea en vero o en prosa...".Relación en la que se elogia sencillamente a los héroes del combate del 21 de octubre..., p. 3.

150 Gaceta de Madrid, 93, 19/11/1805, p. 997.

151 Gaceta de Madrid, 91, 12/11/1805, p. 979.

152 "La reina y yo pensamos en ti. En la ocasión fuiste un héroe y ahora todos necesitamos de ti como amigo. Lo es tuyo como siempre. Carlos y Luisa". AHN, Estado, leg. 2.850-1.

153 Gómez Bueno, P.: Sermón fúnebre predicado en las exequias del Excmo. Sr. D. Federico Gravina, Cádiz, Casa de Misericordia, 1806.
} 
constitucional. ${ }^{154}$ El texto nos interesa aquí por ser una muestra tardía de los ecos del absolutismo ilustrado y un intento de apuntalamiento del pacto dieciochesco mantenido entre un rey patriótico/paternal y un ejército a la vanguardia del bien común. ${ }^{155}$

Sin embargo, podemos apreciar en el discurso la quiebra del sueño de la eternidad absolutista. Al oficial ilustrado se le sigue demandando estudio y arrojo, pero hay una clara insistencia en conceptos como los de "lealtad" y, sobre todo, "subordinación", a los que estaban obligados como súbditos y como cristianos. En un claro repunte del mensaje legitimador religioso, se esperaba de los alumnos que fuesen "buenos cristianos, vasallos fieles, oficiales científicos y valerosos guerreros", con "la virtud religiosa puesta al frente de todos estos deberes y esperanzas". ${ }^{156}$

Al hacer balance de las aportaciones de este tipo de establecimientos, Casa Sarría demuestra que la artillería borbónica contaba con su panteón de héroes particular. El orador destacaba la figura de varios artilleros dignos de imitación por sus conocimientos científicos y literarios, su valor y sus servicios al rey y a la patria. Entre ellos, Vicente de los Ríos ${ }^{157}$, Tomás de Morla, y los héroes del Dos de Mayo (Daoíz y Velarde) y de Bailén: "Hijos eran suyos, alumnos criados en él, nutridos con su doctrina, los héroes que en Bailén brillaron, que tan preciosos lauros recogieron, que hicieron a su patria y al mundo tan inestimable beneficio". ${ }^{158}$

Se pedía a los nuevos cadetes, en definitiva, que devolviesen a la patria lo que esta les daba en forma de instrucción, pero que no olvidasen que su primer deber era la obediencia al rey absoluto. Le quedaba ya poco tiempo de vida a la llamada "utopía reaccionaria"159, a la que la nación ganaría la partida definitivamente.

\section{La oficialidad en el contramodelo (reflexiones finales)}

“... Dios te dé salud amigo Manuel, acierto y te libre de malas voluntades, enfermedades y desgracias que traen consigo una guerra, que sin medios ni gente ni artillería vas a emprender..."

María Luisa de Parma a Godoy, Aranjuez, 3 de Mayo de 1801. ${ }^{160}$

Pocas palabras más demoledoras contra el ejército borbónico que estas escritas por la reina María Luisa a su querido Godoy tras su marcha a la guerra con Portugal; tal vez las -mucho más más conocidas- de Arroyal, que en su Pan y toros representaba un ejército macrocefálico, violeto y opresor "de sus mismos conciudadanos", totalmente distinto del representado por la propaganda oficial.

154 Diego Pareja, L. M. de: La Academia de Ingenieros y el Regimiento de Zapadores de Alcalá de Henares, Alcalá de Henares, Institución de Estudios Complutenses, 1999.

155 Navarro y Sangrán, J.: Discurso pronunciado el día 16 de mayo de 1830 en la abertura de la Real Academia de los Caballeros Cadetes de Artillería en Alcalá de Henares por..., Madrid, Imprenta de M. de Burgos, 1830.

156 Ibidem, p. 10.

157 El propio Ríos ya había esbozado un panteón de ilustres artilleros en una obra ya citada (nota 139). Un proyecto aún más ambicioso fue iniciado en 1807 por Vargas Ponce para la marina (nota 71).

158 Navarro y SANGRÁn, op. cit. (nota 155), pp. 33-34.

159 Luis, J.-P.: L'utopie réactionnaire. Épuration et modernisation de l'État dans l'Espagne de la fin de l'Ancien Régime, Madrid, Casa de Velázquez, 2002.

160 Archivo General de Palacio, Papeles Reservados, t. 94. 
A la hora de estudiar el reformismo dieciochesco es importante diferenciar entre los dispuesto en la legislación y lo que llegaban a alcanzar los limitados medios de la Monarquía. En ese sentido, las palabras de François Lopez sobre aquella época nos ofrecen una visión entre realista y pesimista: "todo fue en las élites de poder y en las élites ideológicas preconizar remedios proclamar grandes principios, ser reformistas más que reformadores, querer y no poder, y, por parte de los gobernados, acatar y no cumplir, sabiendo por experiencia que no siempre van leyes a donde quieren los reyes". ${ }^{161}$

Como historiador cultural, el estudio de los arquetipos implica a veces que algunos colegas consideren que se ha caído en las redes de la leyenda dorada, cuando no se ha hecho sino estudiar ideas, aspiraciones y modelos. Sería un error creer a pies juntillas los elogios oficiales de la época como también lo sería caer en el escepticismo más absoluto.

Es cierto, y ya lo han demostrado especialistas como Cepeda y Andújar, que la monarquía no consiguió la profesionalización y la homogeneización del ejército. En nuestra opinión, no cabe duda de que el siglo XVIII no pasó en vano para una parte del ejército, y personajes como Jorge Juan, Cadalso, Morla, Vargas Ponce o Fernández de Navarrete, dan testimonio, como esperamos haber demostrado, de una formación cultural refinada y una cosmogonía acorde con el nuevo juego de identidades y fidelidades que fueron propias de la élite ilustrada de la segunda mitad del XVIII. Sin embargo, hablamos de un grupo minoritario dentro de un colectivo ya reducido en el ejército como fue el de la oficialidad. ${ }^{162}$

La imagen de los oficiales dieciochescos siguió dejando que desear fuera de los círculos interesados ${ }^{163}$, un desprestigio que no fue exclusivo del ejército español y que podemos encontrar en otros como el inglés. ${ }^{164}$ El mismo Godoy, que tan orgulloso se muestra en sus Memorias de las reformas hechas en el ejército y de los nombres que brillaron durante su ministerio (varios aquí mencionados como Ricardos, Morla y Gravina ${ }^{165}$ ) se lleva la contraria si atendemos a sus escritos de gobierno. Una carta del Generalísimo a Carlos IV, firmada el 28 de marzo de 1802, y previa a las ordenanzas del mismo año, refleja que "la poca ilustración que se ha dado hasta ahora a la oficialidad, las estrecheces de los tiempos, las calamidades y últimas guerras, con otras causas han contribuido a viciar el ramo militar hasta el último grado". Godoy era consciente también de que no era suficiente que los oficiales proviniesen "de buenos pañales", que había que "estimularla con premios, ascensos y salidas cómodas si cumpliese con sus deberes, porque no puede tener energía quien no ve sino un porvenir triste y miserable". ${ }^{166}$

161 Lopez, F.: "Las lenguas de España y la lengua española. De las primeras letras a la literatura", en VV.AA.: El mundo hispánico en el siglo de las Luces, Madrid, UCM, 1996, vol. I, pp.141-159 / 151.

162 “....se formó, eso sí, una élite militar ilustrada -trasposición de la otra minoría militar, la que no llevaba uniforme- muy bien preparada científicamente (...) pero el nivel técnico medio de la oficialidad borbónica, de aquellos artilleros, infantes o ingenieros era muy, muy modesto”. CEPEDA Gómez, op. cit. (nota 70), pp. 34-35.

163 Cit. por García Hurtado, op. cit. (nota 17), p. 51.

164 "Además, nada puede ser tan perjudicial para lo moral de los habitantes de las poblaciones rurales como la residencia temporal de un grupo de jóvenes indolentes y superficiales, cuya sola ocupación es la galantería y cuyos pulidos modales hacen más peligroso el vicio, al disimular su deformidad bajo alegres ropajes ornamentales". Wollstonecraft, Mary: Vindicación de los derechos de la mujer, Madrid, Akal, 2014, p. 56.

165 Godoy, M.: Memorias, Alicante, Universidad de Alicante, 2008, pp. 207-210.

166 Cit. por Herrero FernÁndeZ-QuesadA, op. cit. (nota 3), pp. 912-913. 
Efectivamente, pocos oficiales vivieron el sueño del ejército ilustrado. Junto a su precario poder adquisitivo ${ }^{167}$, si exceptuamos a los más favorecidos por la Corte u otros contactos, muchos sufrieron carreras lentas, como es el caso de los "capitanes con canas, que todavía sirven a los treinta, cuarenta años de ingresar como cadete, a quienes se concede como jubilación honrosa el gobierno de algún fuerte perdido en el fondo de una ría gallega o en un cabo aislado del Mediterráneo". ${ }^{168}$ Podemos percibir las insatisfacciones del servicio en el esplín que volcaba en sus cartas un militar comprometido como Cadalso, frustrado por la soledad del campamento de Montijo y por la falta de oportunidades y ascensos ${ }^{169}$. Un fastidio y un desencanto que, como a otros ilustrados, le llevaba a no esperar salvación alguna para los males del país ${ }^{170}$. Pocos meses antes de encontrar la muerte, se quejaría amargamente ante Floridablanca haciéndole ver "cuán inútil es vivir con amor a la patria o exponerse a morir por ella". ${ }^{171}$

La clave del fracaso del absolutismo ilustrado se encuentra quizás en sus propias bases. Por mucho que la propaganda borbónica intentase fidelizar, como hemos visto, a sus servidores más próximos con un mensaje patriótico, haciéndolos partícipes de un proyecto común en el que la pública felicidad y el mérito llevaban al premio, la realidad fue muy distinta. El fastidio y el hastío fueron una constante en la correspondencia y los diarios de la élite política e intelectual de la época. ${ }^{172}$

Como es lógico, tampoco la monarquía obtuvo de esta élite el compromiso que esperaba. El 27 de noviembre de 1794, se rindió, sin poner resistencia, la moderna y supuestamente inexpugnable fortificación de San Fernando de Figueras, un hecho que, según Andrés Muriel, "llenó todos los ánimos de dolor e indignación" puesto que el fuerte estaba repleto de efectivos y de víveres, y los franceses apenas contaban con artillería para el ataque. Un consejo de guerra formado en 1796 había condenado a muerte y a la degradación militar a los responsables de la plaza, entre ellos al brigadier Andrés de Torres. El propio decreto del rey que perdonaba la vida a los condenados, hablaba de "indecorosa y vil entrega de la plaza", aseguraba que la justicia clamaba por la ejecución y manifestaba la "ignominiosa criminalidad" de los reos. ${ }^{173}$

Concluimos con este ejemplo porque nos recuerda a un pasaje del Espíritu de las leyes. En la obra, Montesquieu incluía a España entre las monarquías, aunque consideraba que había protagonizado actos, como la conquista de América ${ }^{174}$, que la vinculaban a los regímenes despóticos. De haber vivido el philosophe en 1794

167 AndúJar CASTILlo, Francisco: "La situación salarial de los militares en el siglo XVIII", en Balaguer, Emilio y Giménez, Enrique (eds.): Ejército, ciencia y sociedad en la España del Antiguo Régimen, Alicante, Instituto de Cultura Juan Gil-Albert / Diputación de Alicante, 1995, pp. 87-109.

168 DEDIEU, op. cit. (nota 69), p. 245

169 Cadalso, José: Escritos autobiográficos y epistolario, ed. de Nigel Glendinning y Nicole Harrison, London, Tamesis Book Limited, 1979.

170 "Pero, amigo, no hay patria. Todo lo que sea patriotismo es cuando menos inútil, tal vez peligroso (...) De cuando en cuando se ha hecho como que se quería mirar por esta patria, pero a vuelta de una distracción semejante (pues se puede llamar distracción), han retrocedido las gentes al sistema destructor", Cadalso a Iriarte, 1777, en CADALSO, José: Escritos autobiográficos y epistolario, ed. de Nigel Glendinning y Nicole Harrison, London, Tamesis Book Limited, 1979, p. 121).

171 Cadalso a Floridablanca, san Roque, 9 de julio de 1781, en Ibidem, p. 135.

172 Véase el capítulo “Amistad, esplín y conciencia de grupo, en Calvo Maturana, op. cit. (nota 6), pp. $241-261$.

173 Muriel, A.: Historia de Carlos IV, Madrid, Atlas, 1959, tomo I (BAE CXIV), pp. 173-174.

174 Montesquieu, Ch.-L. de Secondat, barón de: El Espíritu de las Leyes, Barcelona, Altaya, 1993, libro 8, cap. XVIII, p. 96. 
quizás habría degradado definitivamente al sistema político español si tenemos en cuenta estas palabras: "Las plazas fuertes son propias de las Monarquías; los Estados despóticos temen tenerlas. No se atreven a confiarlas a nadie, ya que nadie ama al Estado ni al príncipe". ${ }^{175}$ 